\title{
ЭКСПЛОЗИВНОЕ ИЗВЕРЖЕНИЕ ВУЛКАНА БЕЗЫМЯННЫЙ 15 МАРТА 2019 г. И ЕГО ПРОДУКТЫ
}

\author{
(С) 2020 г. О. А. Гирина ${ }^{a, *}$, Н. В. Горбач ${ }^{a}$, В. О. Давыдова ${ }^{b}$, Д. В. Мельников ${ }^{a}$, \\ Т. М. Маневич ${ }^{a}$, А. Г. Маневич ${ }^{a}$, Ю. В. Демянчук ${ }^{a}$ \\ ${ }^{a}$ Институт вулканологии и сейсмологии ДВО РАН, бульвар Пийпа, 9, Петропавловск-Камчатский, 683006 Россия \\ ${ }^{b}$ Геологический факультет Московского государственного университета им. М.В. Ломоносова, \\ Ленинские горы, 1, Москва, 119991 Россия \\ *e-mail: girina@kscnet.ru \\ Поступила в редакцию 28.04.2020 г. \\ После доработки 23.06.2020 г. \\ Принята к публикации 20.08.2020 г.
}

\begin{abstract}
Вулкан Безымянный - один из наиболее активных вулканов Камчатки и мира. В работе описаны подготовка, ход, продукты, динамика и геологический эффект эксплозивного извержения вулкана 15 марта 2019 г., которое было предсказано за 6.5 ч до его начала. Анализ последовательности эруптивных событий проведен с помощью данных видео- и спутникового мониторинга вулкана, количественные характеристики распространения пирокластических отложений получены в информационной системе “Дистанционный мониторинг активности вулканов Камчатки и Курил”. Эксплозии подняли пепел до 15 км над уровнем моря (до 12 км над вулканом), эруптивное облако перемещалось на северо-восток и восток от вулкана, основная площадь территории, на которой отмечались пеплопады, составляла 210.4 тыс. км², в том числе на суше - 15 тыс. км². Кроме тефры, в результате извержения на площади 30 км² образовались отложения пирокластических потоков и пирокластических волн. Общий объем продуктов эксплозивного извержения вулкана оценивается в $0.1-0.2$ $\mathrm{Kм}^{3}$. Продукты извержения относятся к известково-щелочным умереннокалиевым андезибазальтам $\left(\mathrm{SiO}_{2}==54.84-56.29\right.$ мас. \% $)$ и являются наиболее основными разностями среди пород современного эруптивного цикла вулкана Безымянный.
\end{abstract}

Ключевые слова: вулкан, Безымянный, эксплозивное извержение, KVERT, прогноз, видеоданные, спутниковый мониторинг, VolSatView, Камчатка

DOI: $10.31857 / \mathrm{S} 0203030620060139$

\section{ВВЕДЕНИЕ}

Вулкан Безымянный, один из наиболее активных вулканов мира, расположен в центральной части Ключевской группы вулканов Камчатки (рис. 1). Со времени пробуждения вулкана в 1955 г. произошло 52 пароксизмальных эксплозивных извержения вулкана, в том числе катастрофическое 30 марта 1956 г., после которого рост лавового купола в его эксплозивном кратере до конца 2012 г. продолжался почти непрерывно [Girina, 2013; Ozerov et al., 2020]. В течение четырех лет с декабря 2012 до декабря 2016 гг. вулкан находился в состоянии относительного покоя, связанного с высокой эффузивной активностью Трещинного Толбачинского извержения им. 50-летия Института вулканологии и сейсмологии (ИВиС) ДВО РАН в 2012-2013 гг. и четырех извержений вулкана Ключевской в 2012-2013, 2013, 2015 и 2016 гг. [Гирина, 2016; Гирина и др., 2017г].
С декабря 2016 г. до середины 2018 г. отмечалось выжимание вязких лавовых потоков на южный и западные склоны лавового купола вулкана, на фоне которого произошло три сильных эксплозивных извержения с выносом пепла до 15 км над уровнем моря (н.у.м.) (до 12 км над кратером вулкана): 9 марта, 16 июня и 20 декабря 2017 г. [Гирина и др., 2017а-в, 2018а].

В 2018 г. эксплозивных извержений вулкана не наблюдалось, но лавовый купол оставался активным, о чем свидетельствовала почти постоянно отмечавшаяся на спутниковых снимках в его районе термальная аномалия. С 24 марта до 5 ноября 2018 г. температура аномалии была повышенной в связи с ростом и существованием нового небольшого лавового купола, обнаруженного в кратере вулкана при облете на вертолете 9 июля 2018 г. (http://geoportal.kscnet.ru/volcanoes/imgs/2373.jpg). Очередное эксплозивное извержение вулкана произошло в 16:10 UTC (Universal Time Coordinated - универсальное координированное время) 


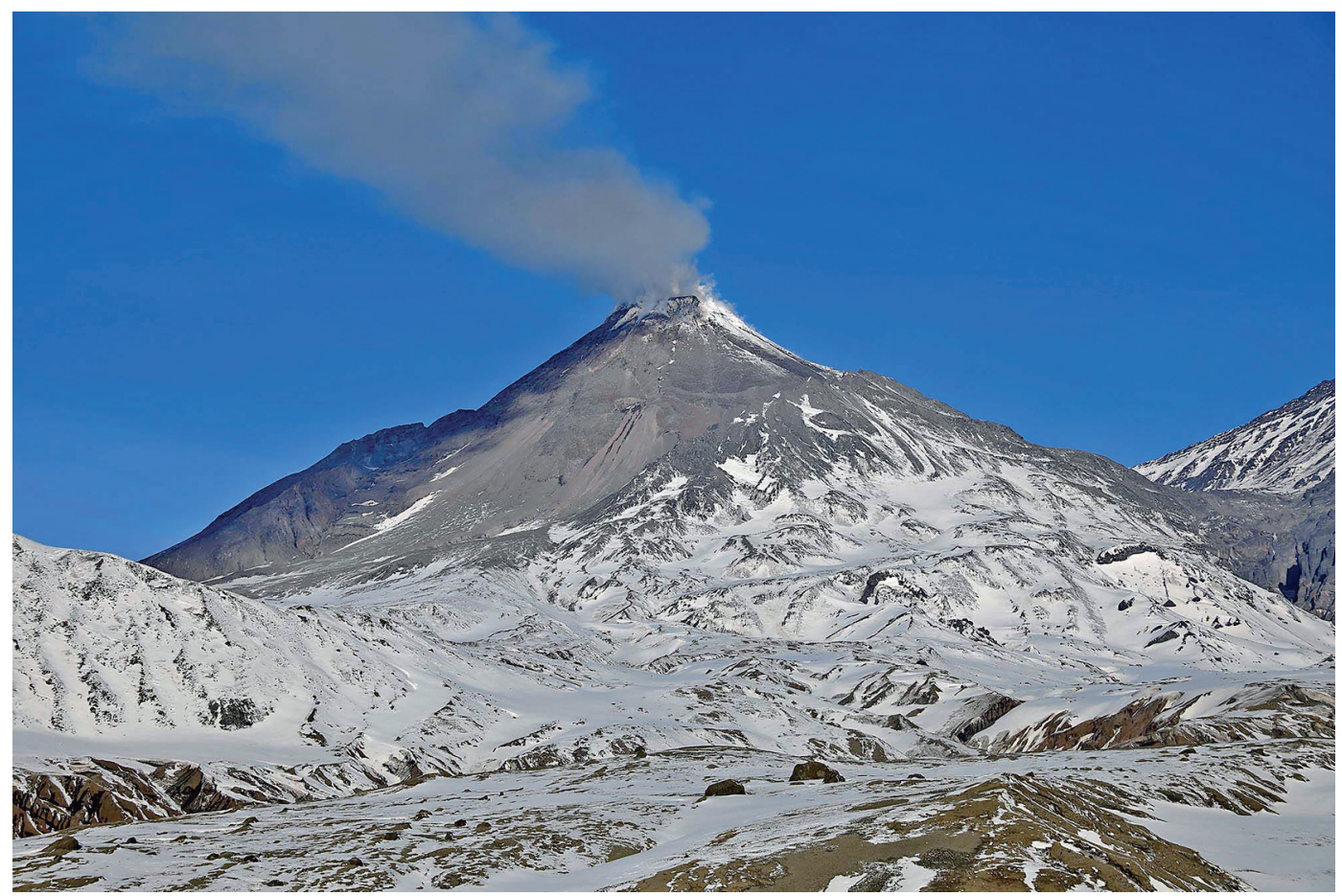

Рис. 1. Состояние вулкана Безымянный 13 апреля 2019 г., на переднем плане - отложения тефры эксплозивного извержения 15 марта 2019 г. Фото Ю. Демянчука с востока от вулкана.

20 января 2019 г.: эруптивная туча поднималась до 7-9 км над кратером вулкана (до 10-12 км н.у.м.) и перемещалась на северо-запад от вулкана. Площадь пеплопадов составила около 200 тыс. км², VEI (Volcanic Explosivity Index) извержения - 2 [Гирина и др., 2018в, 2019б].

Визуальный мониторинг вулкана осушествляется с 1958 г. с сейсмостанции в П. Козыревск. С октября 1960 г. по 27 июня 1989 г. он проводился и со станции Апахончич, пока ее не заменили на телеметрическую. Мониторинг Безымянного с помощью видеокамер выполняется с 20 августа 2003 г. [Гирина и др., 2018б]. Спутниковый мониторинг вулкана проводится учеными Камчатской группы реагирования на вулканические извержения (KVERT - Kamchatkan Volcanic Eruption Response Team) ИВиС ДВО РАН с 2002 г. [Гирина и др., 2018б; Gordeev, Girina, 2014]. Данные о распространении пирокластических отложений (потоков, волн, тефры) на склонах вулкана, а также о направлениях перемещения и размерах эруптивного облака Безымянного в марте 2019 г. были получены с помощью информационной системы (ИС) “Дистанционный мониторинг активности вулканов Камчатки и Курил (VolSatView)" [Гирина и др., 2018б, 2019a; Gordeev et al., 2016]. Работа ИС VolSatView осуществляется благодаря распределенным вычислительным ресурсам Дальневосточного центра НИЦ "Планета”, Центра коллек- тивного пользования (ЦКП) “ИКИ-МониторинГ" (Институт космических исследований РАН) и ЦКП “Центр данных ДВО РАН” (Вычислительный центр ДВО РАН), в которых используются технологии хранения и обработки спутниковой информации, созданные, в том числе, при поддержке гранта РФФИ № 15-29-07953 [Лупян и др., 2014, 2015].

\section{ПОДГОТОВКА, ПРОГНОЗ И ХОД ЭКСПЛОЗИВНОГО ИЗВЕРЖЕНИЯ ВУЛКАНА БЕЗЫМЯННЫЙ 15 МАРТА 2019 Г.}

После эксплозивного извержения 20 января 2019 г. на западный и северо-западный склоны купола Новый вулкана Безымянный происходило выжимание лавовых потоков - по спутниковым данным, величина разности температур термальной аномалии и фона постоянно была повышенной (рис. 2). С 23 февраля температура аномалии начала повышаться - в ночное время на видеокадрах стали отмечаться свечение в районе кратера вулкана и обрушения раскаленных лавин на восточные склоны лавового купола, указывавшие на поступление в кратер вулкана свежего ювенильного вещества - на начало экструзивной фазы извержения, которая на Безымянном предваряет эксплозивную [Girina, 2013]. 


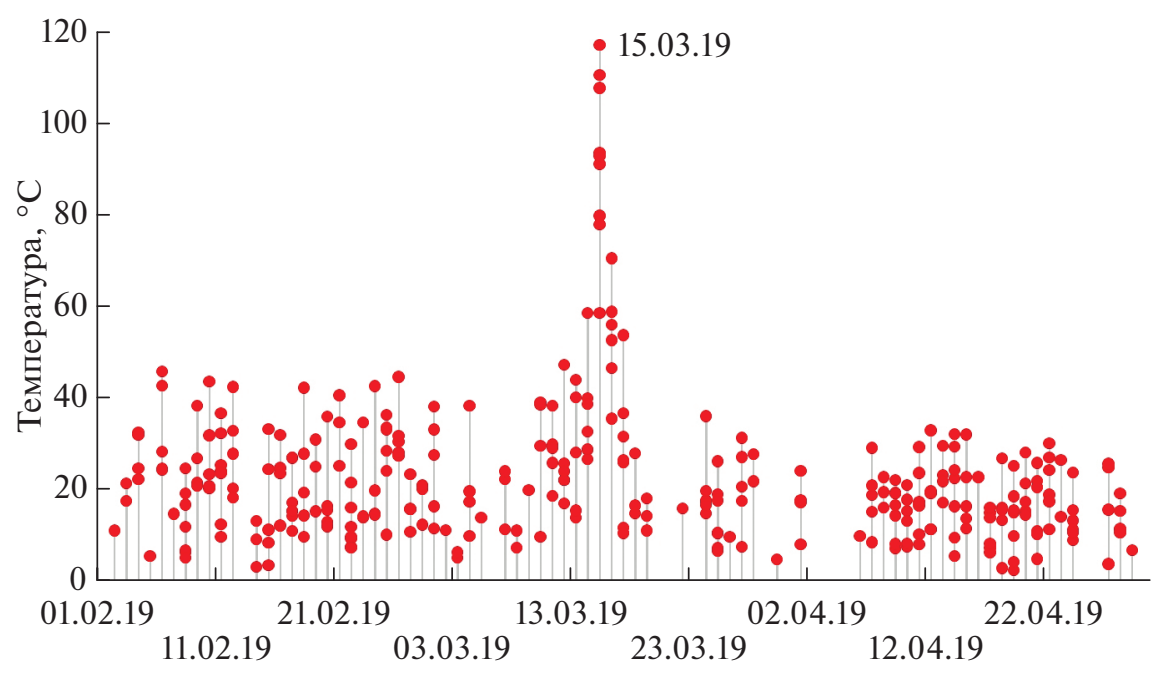

Рис. 2. Изменение величины разницы температур термальной аномалии и фона вулкана Безымянный в феврале-апреле 2019 г. по данным обработки спутниковой информации среднего разрешения в ИС VolSatView.

На основании постепенного нарастания активности вулкана, 26 февраля 2019 г. учеными KVERT было выпущено предупреждение для авиации (Volcano Observatory Notice for Aviation, VONA), в котором Авиационный цветовой код (АЦК) опасности вулкана был изменен с желтого на оранжевый (http://www.kscnet.ru/ivs/kvert/van/?n=2019-43). В прогнозе было указано, что эксплозивное извержение с выносом пепла до 10-15 км н.у.м. (712 км над кратером) возможно в течение нескольких дней.

С 5 марта количество раскаленных лавин стало увеличиваться, с 10 марта температура термальной аномалии начала неуклонно расти (см. рис. 2). 12 марта в сообщении VONA был уточнен прогноз развития извержения: эксплозивное извержение с выносом пепла до 10-15 км н.у.м. (до 7-12 км над кратером) может произойти в течение следующей недели (http://www.kscnet. $\mathrm{ru} / \mathrm{ivs} / \mathrm{kvert} / \mathrm{van} / \mathrm{n}=2019-60)$.

Количество раскаленных лавин, спускавшихся по северо-восточному и восточному склонам купола, продолжало расти, объем их увеличивался (рис. 3). С 00:30 до 03:00 UTC 15 марта в парогазовых шлейфах вулкана отмечался пепел, шлейф протягивался на юго-восток от вулкана до 100 км. C 07:30 UTC 15 марта температура термальной аномалии в районе вулкана стала резко расти (см. рис. 2). С 08:15 UTC над вулканом начала формироваться вертикальная парогазовая колонна, в которую иногда подмешивался пепел от крупных раскаленных лавин. В 11:00 UTC 15 марта в сообщении VONA KVERT АЦК опасности вулкана был изменен с оранжевого на красный и в прогнозе было указано, что эксплозивное извержение с выносом пепла до 10-15 км н.у.м. (7-
12 км над кратером) возможно в течение этой ночи (http://www.kscnet.ru/ivs/kvert/van/?n=2019-63).

Пароксизмальное эксплозивное извержение Безымянного с выносом пепла до 15 км н.у.м. (12 км над кратером) началось в 17:30 UTC 15 марта, сообщение VONA об этом было выпущено KVERT в 17:37 UTC 15 марта (http://www.kscnet.ru/ivs/kvert/van/?n=2019-64). Прогноз KVERT был реализован через 6.5 ч после публикации.

Согласно видеоданным, взрывы в кратере лавового купола Безымянного и крупные раскаленные лавины, которые обрушивались на его восточные склоны, стали отмечаться с 17:10 UTC 15 марта. B 17:22 UTC наблюдались ярчайшие вспышки, прорезавшие темноту ночи - произошло несколько мощных взрывов, в результате которых на все склоны вулкана начали обрушиваться раскаленные лавины и пирокластические потоки, над вулканом стала подниматься эруптивная колонна, которая к 17:27 UTC достигла 10-12 км н.у.м. (79 км над вулканом). В 17:29-17:45 UTC произошла серия наиболее сильных, вероятно, направленных взрывов, в результате которых эруптивное облако поднялось до 15 км н.у.м. и со скоростью 60-80 км/ч [Гирина и др., 2020] двигалось на северо-восток от вулкана (рис. 4). По спутниковым данным из ИС VolSatView, в момент главного взрыва (17:40 UTC) разница температур термальной аномалии и фона достигала $117^{\circ} \mathrm{C}$ (см. рис. 2). Азимут распространения пеплового облака в течение часа (с 17:30 до 18:30 UTC) изменился с $54^{\circ}$ до $80^{\circ}$ [Гирина и др., 2020], далее пепловый шлейф перемещался на восток от вулкана (рис. 5а).

В соответствии с видео- и спутниковыми данными, непрерывный вынос пепла из вулкана, формирование пирокластических потоков и пеплового 


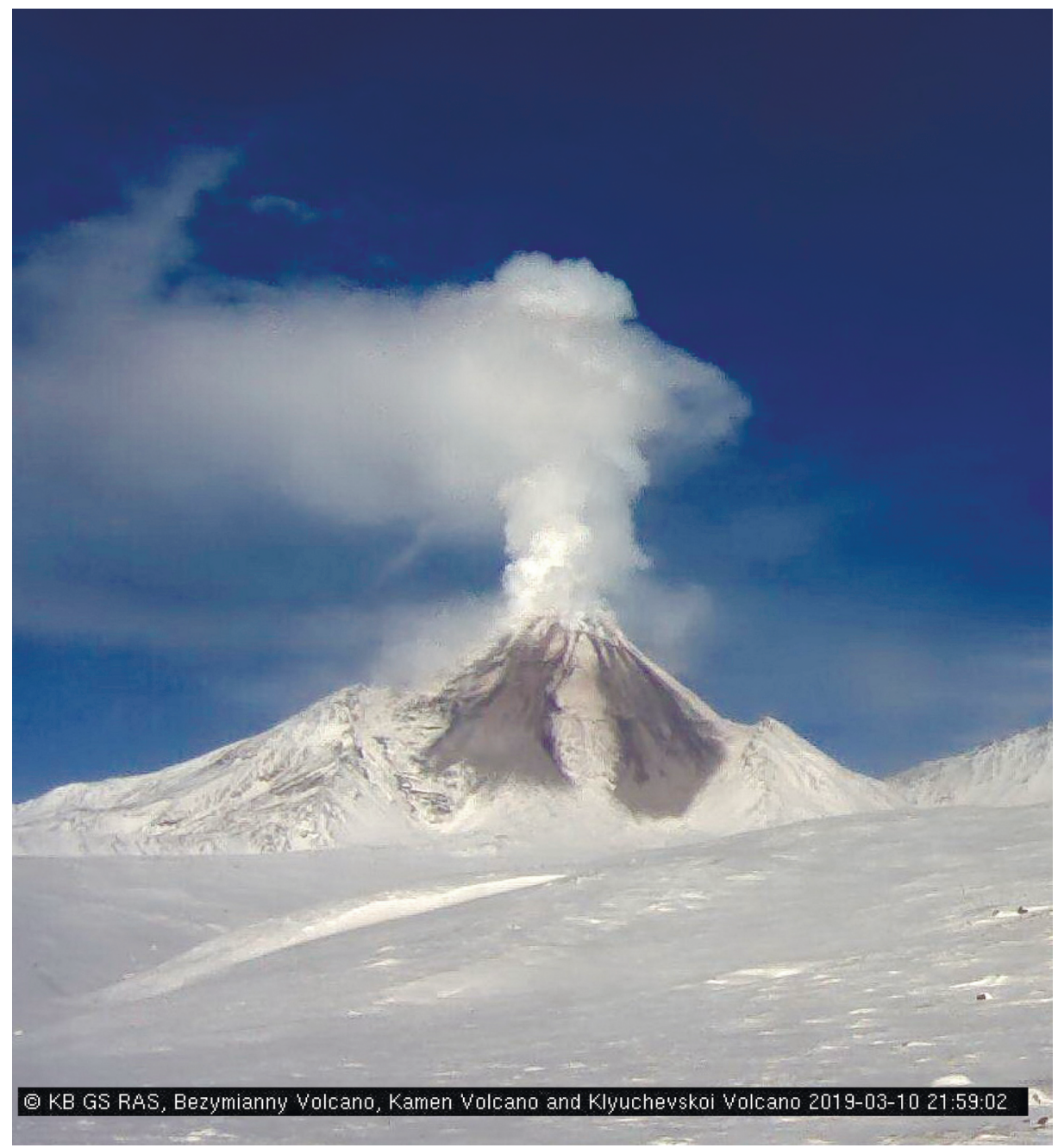

Рис. 3. Следы непрерывных раскаленных лавин на восточном и северо-восточном склонах купола Новый Безымянного 10 марта 2019 г. Видеоданные КФ ФИЦ ЕГС РАН с восточного склона вулкана.

шлейфа происходили примерно до 00:10 UTC 16 марта, т.е. эксплозивная фаза извержения продолжалась около 7.5 ч, далее на протяжении нескольких дней наблюдалась мощная парогазовая активность вулкана.

По сейсмическим данным Камчатского филиала Федерального исследовательского центра “Единая геофизическая служба РАН", пароксизм длился 4 ч, величина вулканического дрожания составляла 0.12 мкм/c (www.emsd.ru/ ssl/monitoring/).

Согласно спутниковым данным из ИC VolSatView, южный край пеплового шлейфа достиг северной части о. Беринга (Командорские о-ва) примерно к 22:30 UTC 15 марта, к 02:00 UTC 16 марта пепловое облако уже полностью перекрывало остров, пеплопад на котором продолжался примерно до 04:00 UTC 16 марта. По визуальным данным Е. Мамаева с о. Беринга, обильный пеплопад на самом северном мысе острова - мы- се Юшина - начался в 23:30 UTC 15 марта. Судя по фотографиям Е. Мамаева, за время пеплопада (3-4 ч) на поверхности острова пепел отложился в разных местах слоем мощностью от 0.3 до $1.0 \mathrm{~cm}$ (см. рис. 5б).

По данным со спутника Himawari-8 в ИС VolSatView, с 17:30 15 марта до 03:00 UTC 16 марта площадь эруптивного облака Безымянного уве-

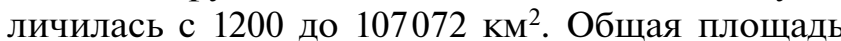
пеплопадов, связанных с распространением эруптивного облака вулкана, к 03:00 UTC 16 марта составляла 210.4 тыс. км² [Гирина и др., 2020].

После окончания извержения в районе кратера вулкана в течение нескольких месяцев продолжала фиксироваться яркая термальная аномалия (см. рис. 2), в темное время суток отмечалось свечение его вершины, отражавшие вероятное выжимание нового лавового потока на северо-западный склон купола. 


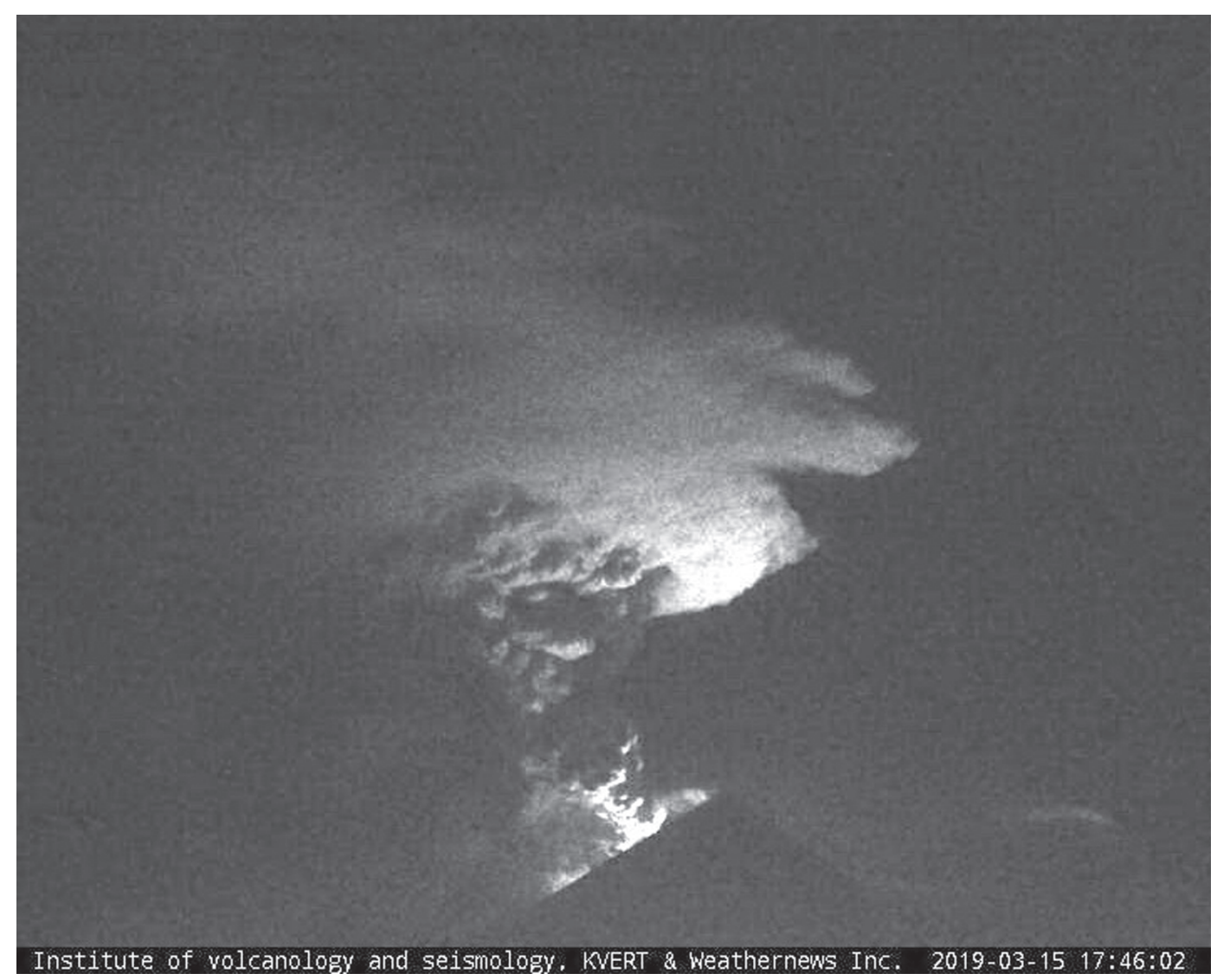

Рис. 4. Эруптивные колонна и облако вулкана Безымянный во время эксплозивного извержения 15 марта 2019 г., на первом плане - конус вулкана Ключевской. Вид с Камчатской вулканологической станции им. Ф.Ю. Левинсона-Лессинга с севера от вулкана. Видеоданные KVERT (ИВиС ДВО РАН) и Weathernews Inc.

\section{ПРОДУКТЫ ЭКСПЛОЗИВНОГО ИЗВЕРЖЕНИЯ ВУЛКАНА БЕЗЫМЯННЫЙ 15 MAPTA 2019 г. \\ Teфpa}

Во время отбора проб тефры вместе со снегом 9-13 апреля 2019 г. сотрудниками Камчатской вулканологической станции им. Ф.Ю. Левинсона-Лессинга ИВиС ДВО РАН было отмечено наличие в ней остроугольных обломков пористых лав Безымянного размером до 7-9 см на расстояниях 10-12 км от вулкана.

Как показал анализ проб тефры, выполненный в ИВиС ДВО РАН, ближе к краю пеплопада (т. 8, 16 км от вулкана) вес пепла составил 280 г/м м $^{2}$ вблизи ст. Апахончич (15.5 км от вулкана) $-1.1 \mathrm{kг} / \mathrm{M}^{2}$. Ближе к оси распространения отложений тефры (т. 4-6, в 17.6-23 км от вулкана), ее вес был от 3.6 до 4.4 кг $/ \mathrm{M}^{2}$, в этих образцах наблюдались лапилли размером до 3 см. Преобладающими фракциями в отложениях тефры на краю пеплопада были 0.5-1.0 мм, ближе к оси ее распространения - 2-4 мм, т.е. материал тефры был крупно- и грубозернистый (рис. 6). В составе крупных фракций тефры наряду с преобладанием зеленоватых высокопористых частиц отмечались угловатые плотные светло- и темно-серые обломки, последние насыщены плагиоклазом. В составе других фракций (кроме тонких) частицы тефры округлены, представлены преимущественно обломками лав свежего облика от светлых белесых до черных оттенков, имеется также некоторая доля минералов и их сростков (плагиоклаз, пироксены, титаномагнетит) и единичные резургентные частицы (обломки пород темно-алого цвета). В тонких фракциях частицы представлены преимущественно вулканическим стеклом (до 80\%), плагиоклазом, пироксенами, титаномагнетитом.

По химическому составу образцы тефры, отобранные на расстояниях 15.5-23 км от вулкана, отличаются от исследованных лав и заполнителей пирокластических потоков и волн несколько пониженными содержаниями $\mathrm{FeO}, \mathrm{MgO}$ и $\mathrm{K}_{2} \mathrm{O}$ и повышенными $\mathrm{Al}_{2} \mathrm{O}_{3}, \mathrm{CaO}$ и $\mathrm{Na}_{2} \mathrm{O}$ (табл. 1). В водных вытяжках из шести проб тефры значения $\mathrm{pH}$ варьируются от 5.85 до 6.5, диапазон содержания компонентов (в мг-экв, \%) составляет: $\mathrm{HCO}_{3}^{-}$от 14.23 до 47.05 (в среднем, 27.95), $\mathrm{Cl}^{-}$от 17.76 до 
(a)

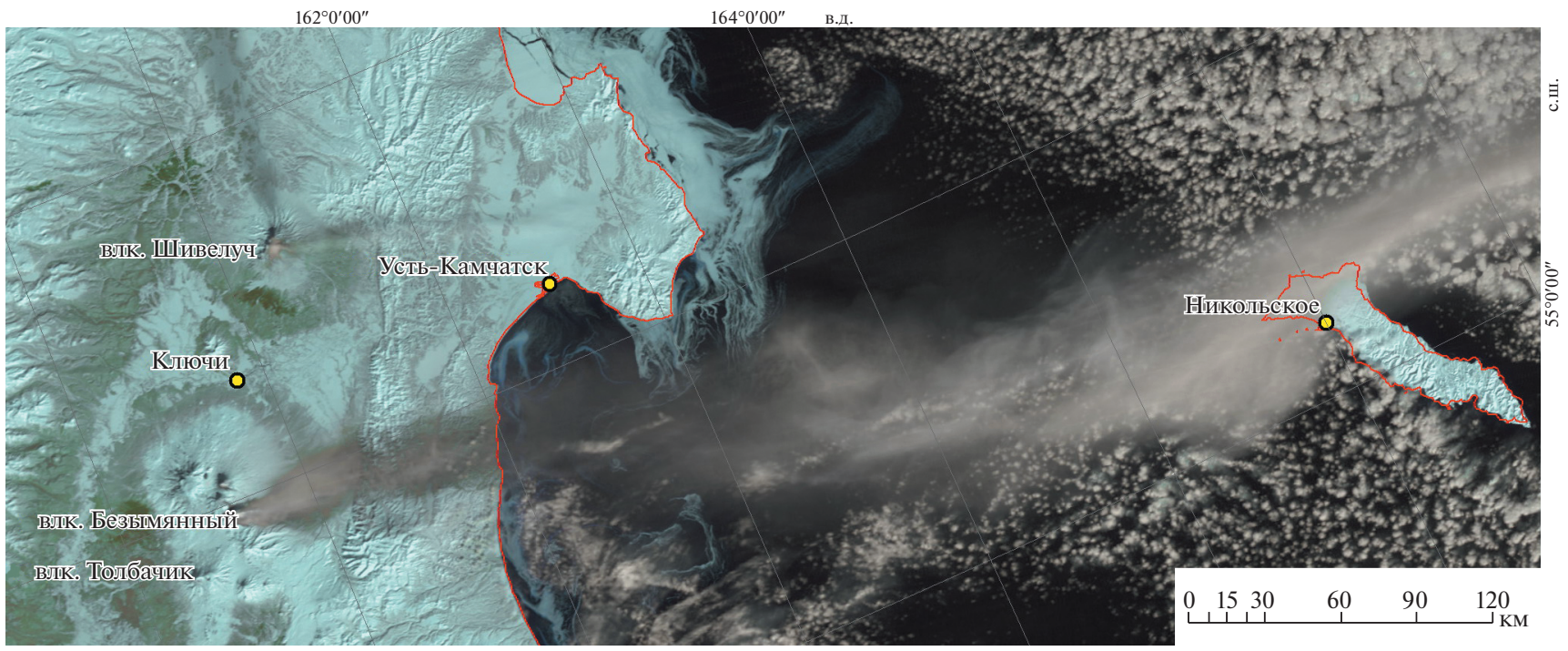

(б)

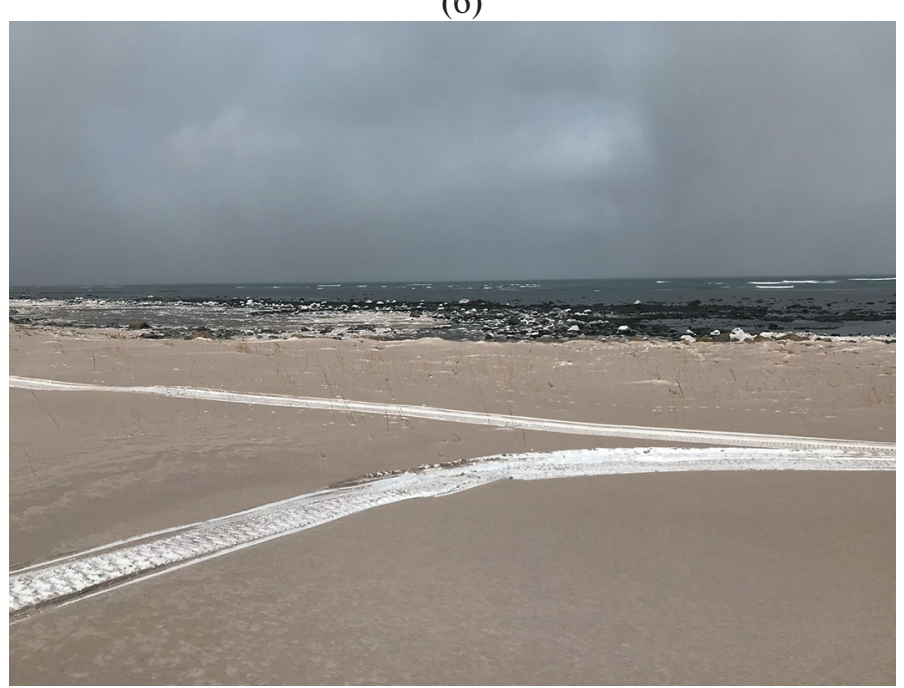

Рис. 5. Пепловый шлейф от вулкана Безымянный во время эксплозивного извержения 15 марта 2019 г. и отложения пепла на о. Беринга: а - шлейф пепла на снимке со спутника Terra MODIS от 00:01 16 марта 2019 г., данные из ДЦ ФГБУ НИЦ Планета; б - пепел на снегу на мысе Юшина в северной части о. Беринга 15 марта 2019 г. Фото Е. Мамаева.

26.12 (22.68), $\mathrm{SO}_{4}^{2-}$ от 22.05 до 60.19 (40.79), $\mathrm{F}^{-}$от 5.26 до 12.25 (8.39), $\mathrm{Na}^{+}$от 11.26 до $26.96(20.9), \mathrm{Ca}^{2+}$ от 65.99 до 84.71 (73.01), $\mathrm{Mg}^{2+}$ от 4.03 до 8.64 (6.08) (анализ водных вытяжек из пепла выполнен в Аналитическом центре ИВиС ДВО РАН). Повышенное содержание в эруптивных облаках газов группы серы является типичным для вулкана Безымянный [Башарина, 1966; Дубик, Меняйлов, 1969], галоидов в них меньше.

\section{Отложения пирокластических потоков и волн}

Согласно спутниковым данным, полученным 16 марта 2019 г., образования пирокластики наблюдались на юго-восточных, восточных и севе- ро-восточных склонах вулкана (рис. 7). По данным из ИС VolSatView, протяженность отложений пирокластических потоков на западном склоне была 3.5-4 км, в долине Восточная - около 8 км, на юго-восточном склоне в каньоне у экструзии Лохматый -7 км. Площадь образований пирокластических потоков и пирокластических

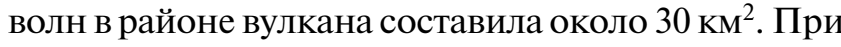
мощности отложений пирокластических потоков от 1.5 до 20 м и мощности пирокластических волн до 2 м, объем отложений пирокластических потоков и волн оценивается в $0.1-0.2 \mathrm{kм}^{3}$.

Полевые исследования пирокластических отложений извержения были проведены в начале июля 2019 г. 


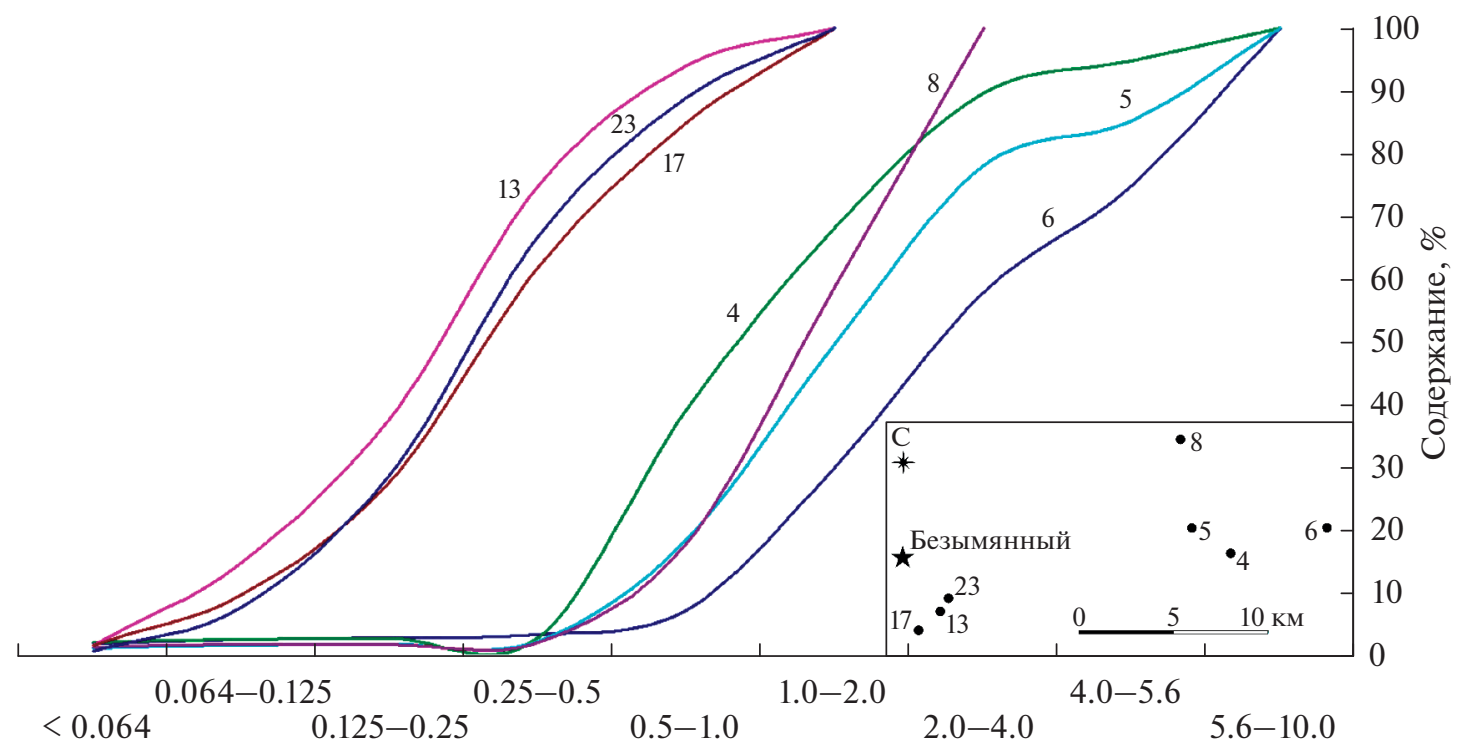

Рис. 6. Кумулятивные кривые гранулометрического состава образцов пирокластических отложений вулкана Безымянный эксплозивного извержения 15 марта 2019 г.

Тефра: ближе к оси распространения отложений (4-6), ближе к их краю (8); заполнители отложений пирокластических потоков (17) и пирокластических волн (13 и 23). На врезке показано расположение точек отбора пирокластики относительно вулкана.

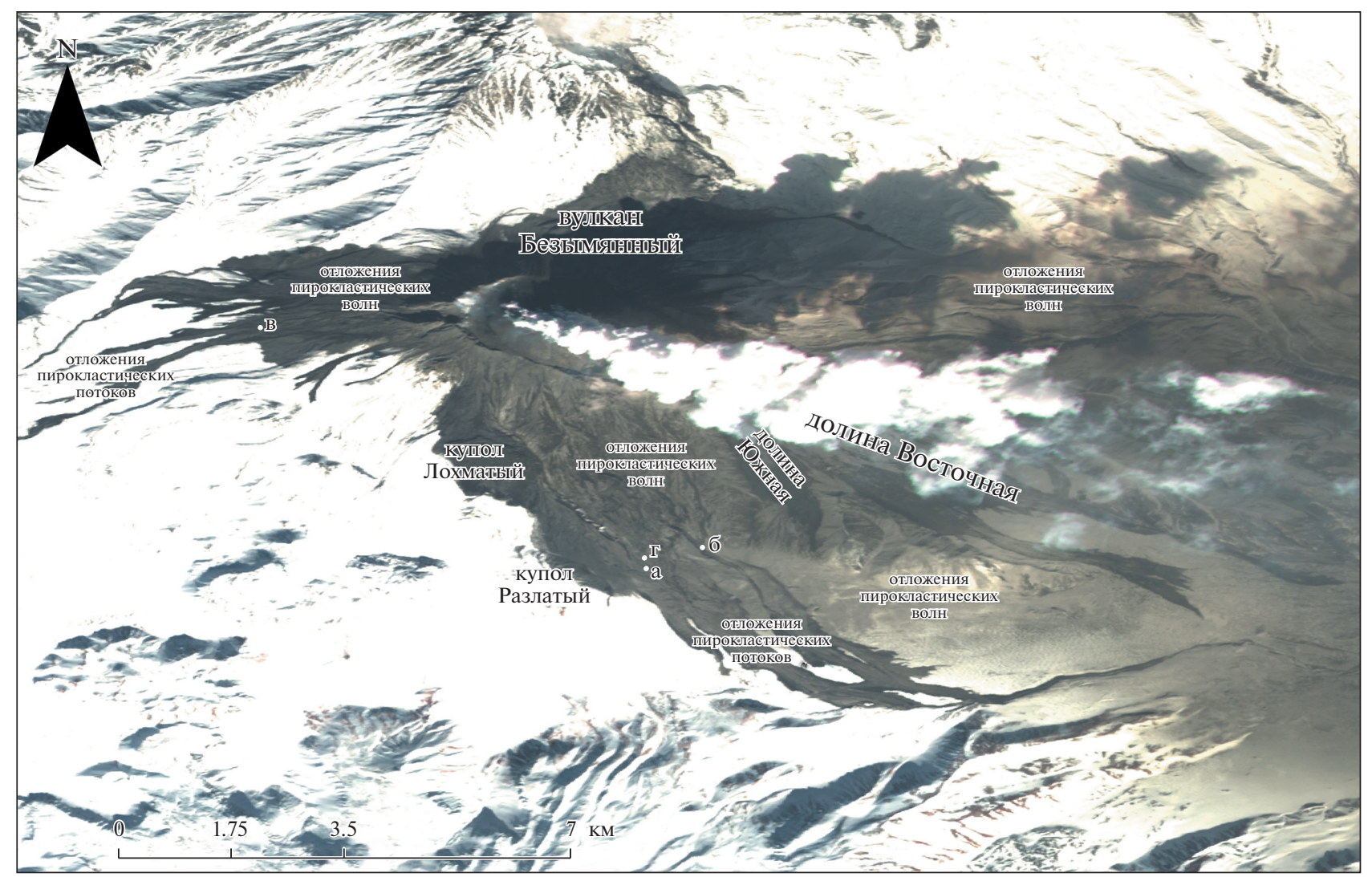

Рис. 7. Отложения пирокластических потоков и волн на склонах вулкана Безымянный после эксплозивного извержения 15 марта 2019 г. Снимок со спутника Sentinel-2B в 00:30 UTC 16 марта 2019 г. из ИС VolSatView. Точки - a-г - coответствуют изображениям (см. рис. 8). 
Таблица 1. Химический состав продуктов эксплозивного извержения вулкана Безымянный 15 марта 2019 г.

\begin{tabular}{|c|c|c|c|c|c|c|c|c|c|}
\hline № п/П & 1 & 2 & 3 & 4 & 5 & 6 & 7 & 8 & 9 \\
\hline № обр. & 7761-1 & $7761-2$ & ГБ-4 & ГБ-6 & ГБ-7 & ГБ-13 & ГБ-17 & ГБ-22 & ГБ-23 \\
\hline $\mathrm{SiO}_{2}$ & 56.11 & 55.58 & 55.15 & 55.13 & 56.48 & 55.28 & 55.65 & 54.95 & 54.72 \\
\hline $\mathrm{TiO}_{2}$ & 0.81 & 0.78 & 0.62 & 0.70 & 0.59 & 0.76 & 0.74 & 0.77 & 0.76 \\
\hline $\mathrm{Al}_{2} \mathrm{O}_{3}$ & 18.38 & 18.44 & 20.51 & 19.88 & 19.84 & 18.32 & 18.82 & 18.26 & 18.42 \\
\hline $\mathrm{FeO}$ & 8.43 & 8.16 & 6.97 & 7.71 & 6.61 & 8.61 & 8.50 & 8.59 & 8.78 \\
\hline $\mathrm{MnO}$ & 0.15 & 0.15 & 0.13 & 0.14 & 0.12 & 0.16 & 0.16 & 0.16 & 0.16 \\
\hline $\mathrm{MgO}$ & 4.35 & 4.24 & 3.63 & 3.91 & 3.68 & 4.75 & 4.71 & 4.50 & 4.78 \\
\hline $\mathrm{CaO}$ & 8.15 & 8.27 & 8.99 & 8.77 & 8.40 & 8.28 & 8.43 & 8.10 & 8.36 \\
\hline $\mathrm{Na}_{2} \mathrm{O}$ & 3.27 & 3.23 & 3.35 & 3.29 & 3.60 & 3.16 & 3.13 & 3.14 & 3.08 \\
\hline $\mathrm{K}_{2} \mathrm{O}$ & 1.06 & 1.04 & 0.86 & 0.87 & 0.90 & 0.92 & 0.89 & 0.94 & 0.88 \\
\hline $\mathrm{P}_{2} \mathrm{O}_{5}$ & 0.15 & 0.14 & 0.11 & 0.12 & 0.11 & 0.13 & 0.12 & 0.13 & 0.12 \\
\hline П.п.п. & -0.09 & -0.06 & 0.08 & -0.06 & 0.06 & -0.07 & 0.11 & 0.04 & -0.02 \\
\hline Сумма & 100.84 & 100.04 & 100.49 & 100.54 & 100.49 & 100.38 & 101.34 & 99.66 & 100.12 \\
\hline $\mathrm{V}$ & 232 & 215 & 174 & 201 & 160 & 221 & 210 & 222 & 217 \\
\hline $\mathrm{Cr}$ & 25 & 22 & 26 & 39 & 40 & 32 & 36 & 27 & 29 \\
\hline $\mathrm{Co}$ & 24 & 27 & 19 & 22 & 19 & 24 & 23 & 26 & 26 \\
\hline $\mathrm{Ni}$ & 20 & 20 & 18 & 18 & 21 & 22 & 22 & 20 & 21 \\
\hline $\mathrm{Cu}$ & 51 & 53 & 45 & 50 & 42 & 37 & 39 & 39 & 37 \\
\hline $\mathrm{Zn}$ & 81 & 80 & 66 & 73 & 62 & 78 & 78 & 81 & 84 \\
\hline $\mathrm{Y}$ & 24 & 23 & 18 & 19 & 18 & 19 & 18 & 23 & 20 \\
\hline $\mathrm{Zr}$ & 95 & 102 & 73 & 79 & 73 & 85 & 81 & 85 & 79 \\
\hline
\end{tabular}

Примечание. Содержания петрогенных оксидов приведены в мас. \%, микроэлементов - в г/т. Образцы 1, 2 - фрагменты ювенильных лав из отложений пирокластических потоков; $3-5$ - тефра, отобранная в районе стационара ИВиС ДВО РАН Апахончич и близко к оси пеплопада; 6,9 и 7, 8 - заполнители отложений, соответственно, пирокластических волн и пирокластических потоков в каньоне у экструзивного купола Лохматый $(6,7)$ и в долине Восточная $(8,9)$. Содержания главных элементов и ряда микроэлементов в породах определялись при помощи рентгенофлуоресцентного анализа в Центре коллективного пользования изотопно-геохимических исследований Института геохимии им. А.П. Виноградова СО РАН, г. Иркутск.

Отложения пирокластических потоков были обнаружены во всех долинах и ложбинах на всех склонах Безымянного. Например, до извержения вулкана каньон, расположенный у северо-восточного подножия экструзии Лохматый, в средней части имел $\mathrm{V}$-образный профиль и был глубиной более 20 м. В результате эксплозивного извержения эта часть каньона наполовину была заполнена отложениями пирокластического потока и приобрела корытообразный профиль. На выходе из каньона нагромождения блоков лав потока превышали 2-3 м над его бортами. Отмечалась порционность поступления материала пирокластического потока - мощность отдельных порций, выраженных в рельефе, достигала 10 м.

В пирокластическом потоке резко преобладали пористые глыбы лавы размером до 3-4 м зеленовато-серо-коричневого цвета снаружи и темно-серого до черного внутри. В потоке также отмечались плотные разности пород от серого до черного цвета размером до 1.5 м (рис. 8a). На поверхности пористых глыб наблюдались следы “мягких" деформаций (смятий) от соударений с другими блоками. Все глыбы были округлены, разбиты многочисленными трещинами. Вероятно, такие лавовые глыбы во время извержения вулкана были очень горячими, пластичными, насыщенными газом. Во время движения в потоке глыбы сминались в моменты ударов о препятствия (борта каньона, другие глыбы и т.д.) и в результате резкой дегазации разбивались трещинами - подтверждением этому является наличие вспененной породы внутри трещин. Плотность ненарушенного сложения заполнителя отложений потока в июле 2019 г. варьировалась в преде-

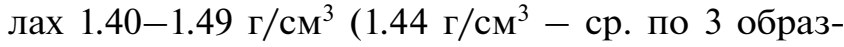
цам). Заполнитель отложений пирокластического потока был представлен среднезернистым песком зеленоватого оттенка с преобладанием частиц размером 0.25-0.5 мм (см. рис. 6).

В глубокой долине, соседней с каньоном, отложений пирокластического потока было относительно немного - их мощность не превышала 3 м, они были равномерно распределены по долине, 
(a)

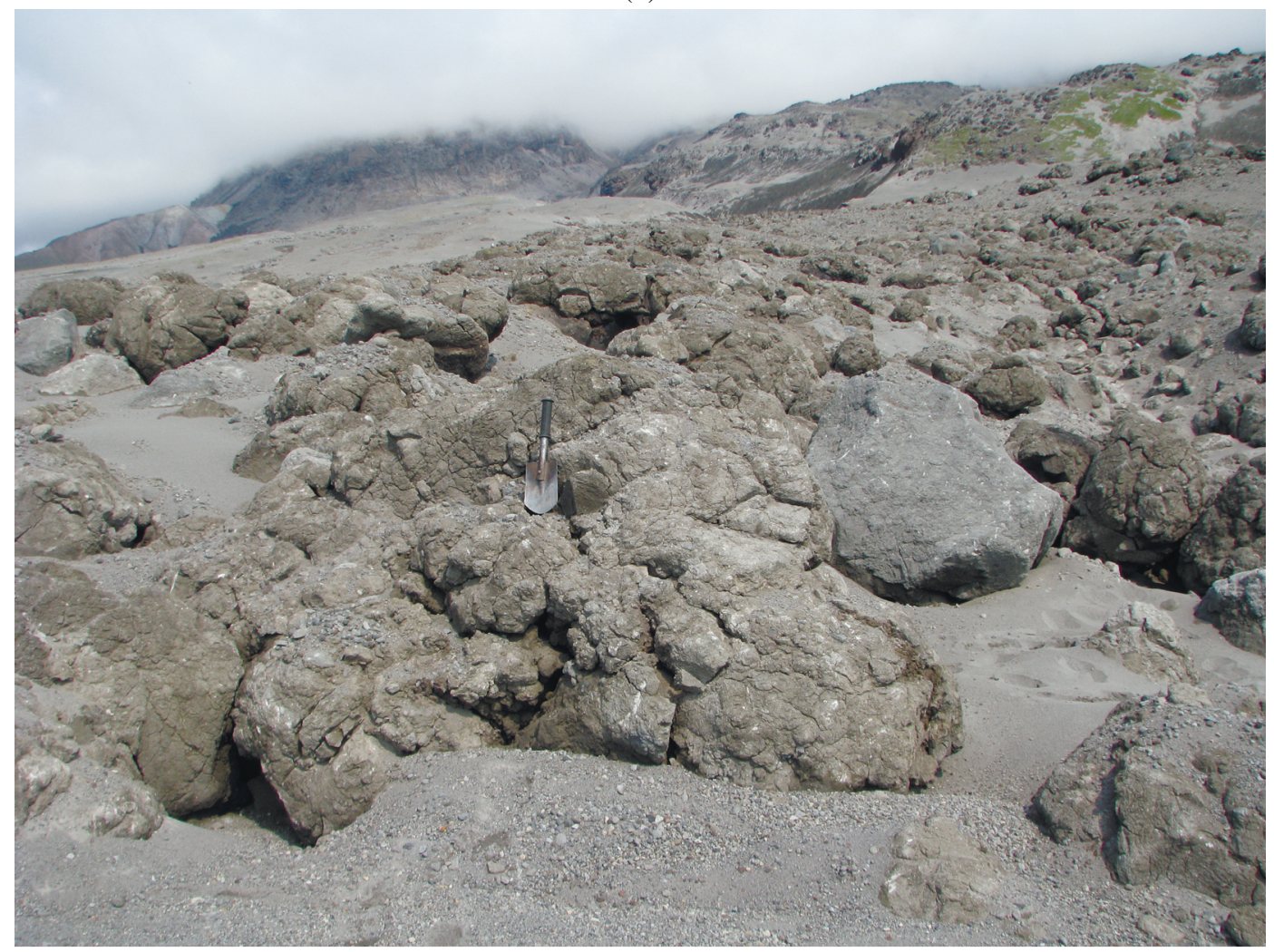

(б)

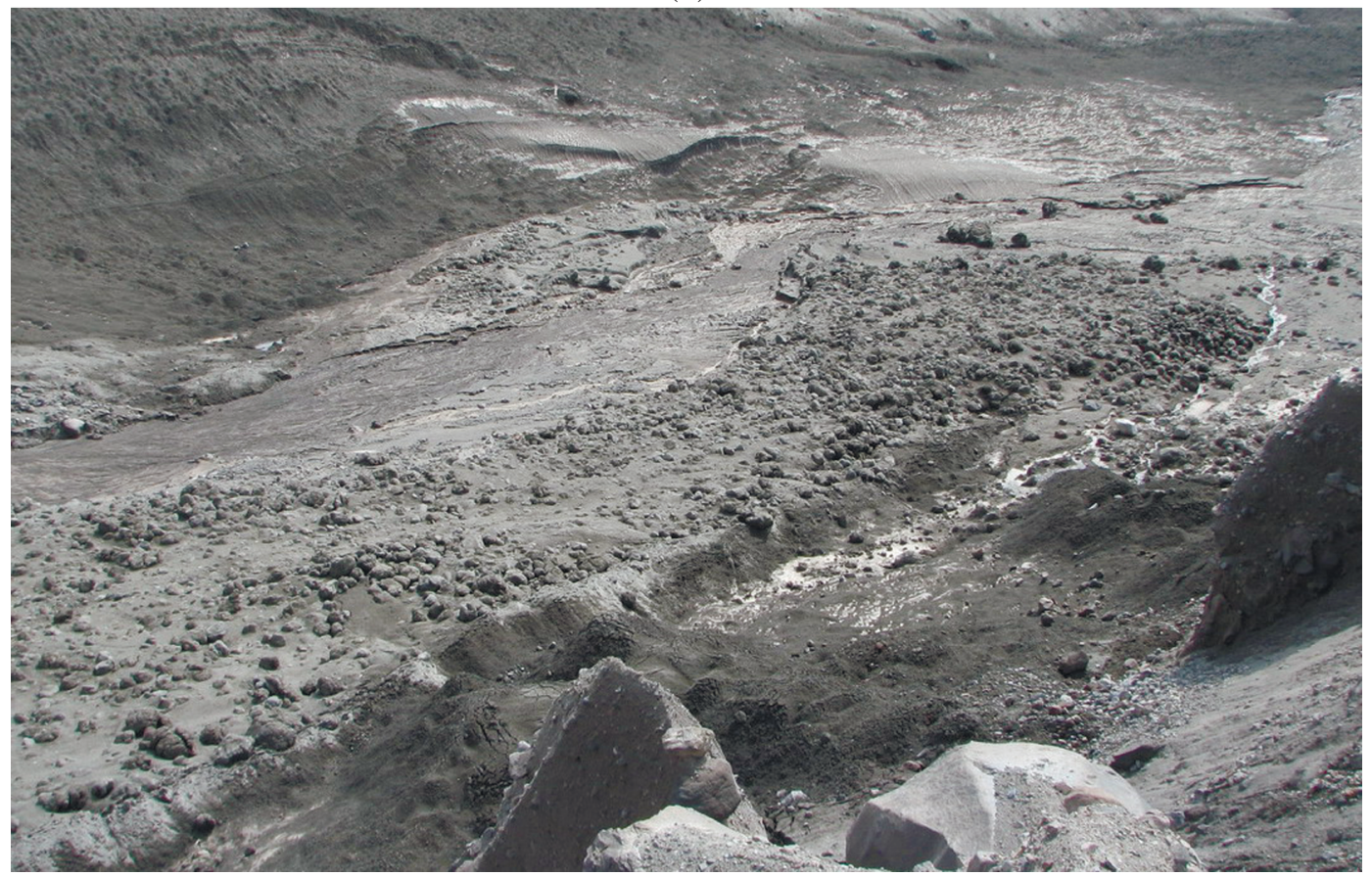

Рис. 8. Пирокластические отложения эксплозивного извержения вулкана Безымянный 15 марта 2019 г.

Отложения пирокластических потоков: а - на выходе из каньона у экструзии Лохматый (длина лопатки - 35 см), б в соседней с каньоном долине, в - в ложбине на западном склоне вулкана (высота рюкзака - 70 см), г - дюнный рельеф отложений пирокластических волн слева от каньона у экструзии Лохматый, рядом с ними - отложения пирокластического потока на выходе из каньона. Описание отложений в тексте. Фото О. Гириной (а-в), В. Давыдовой (г). 
(в)

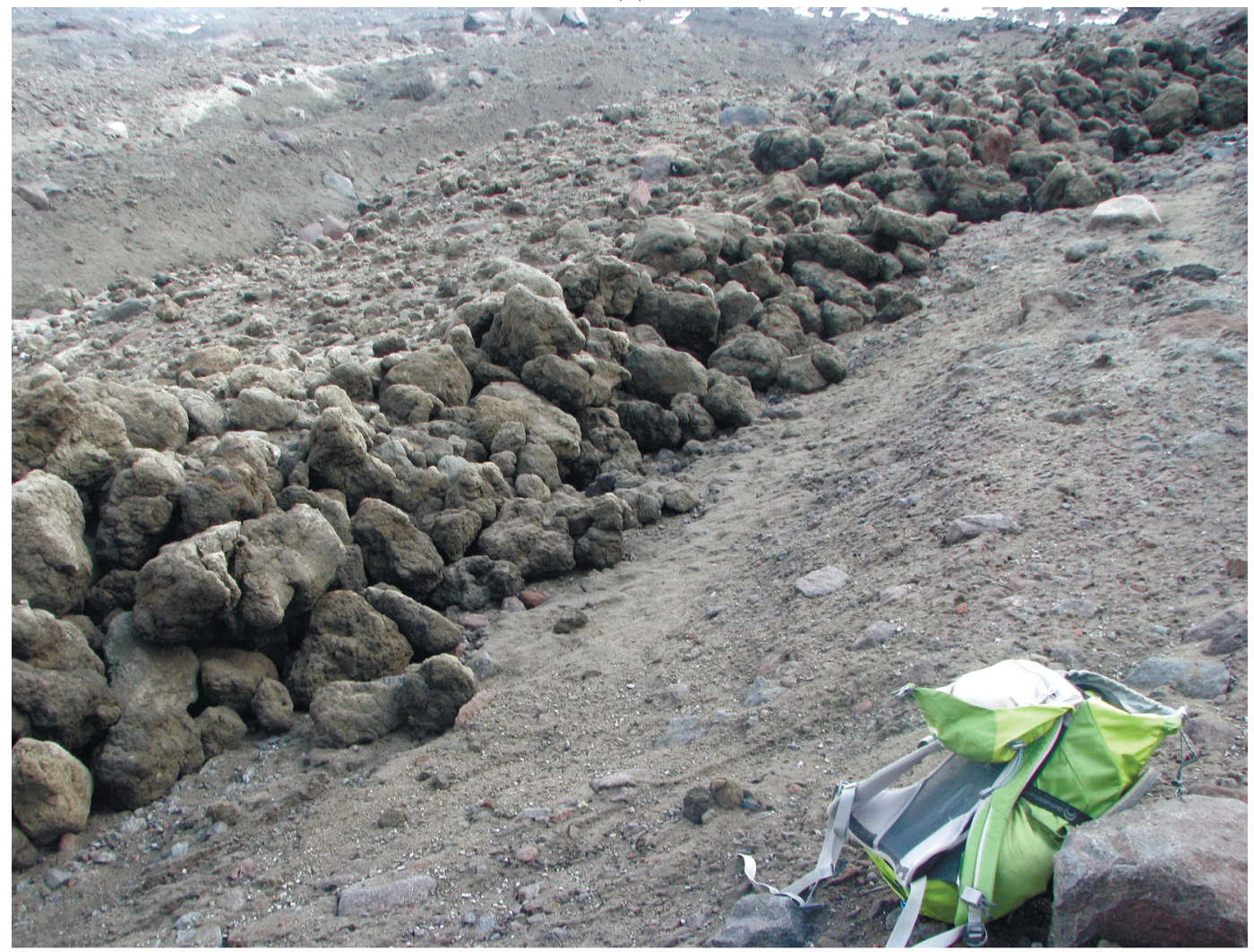

(г)

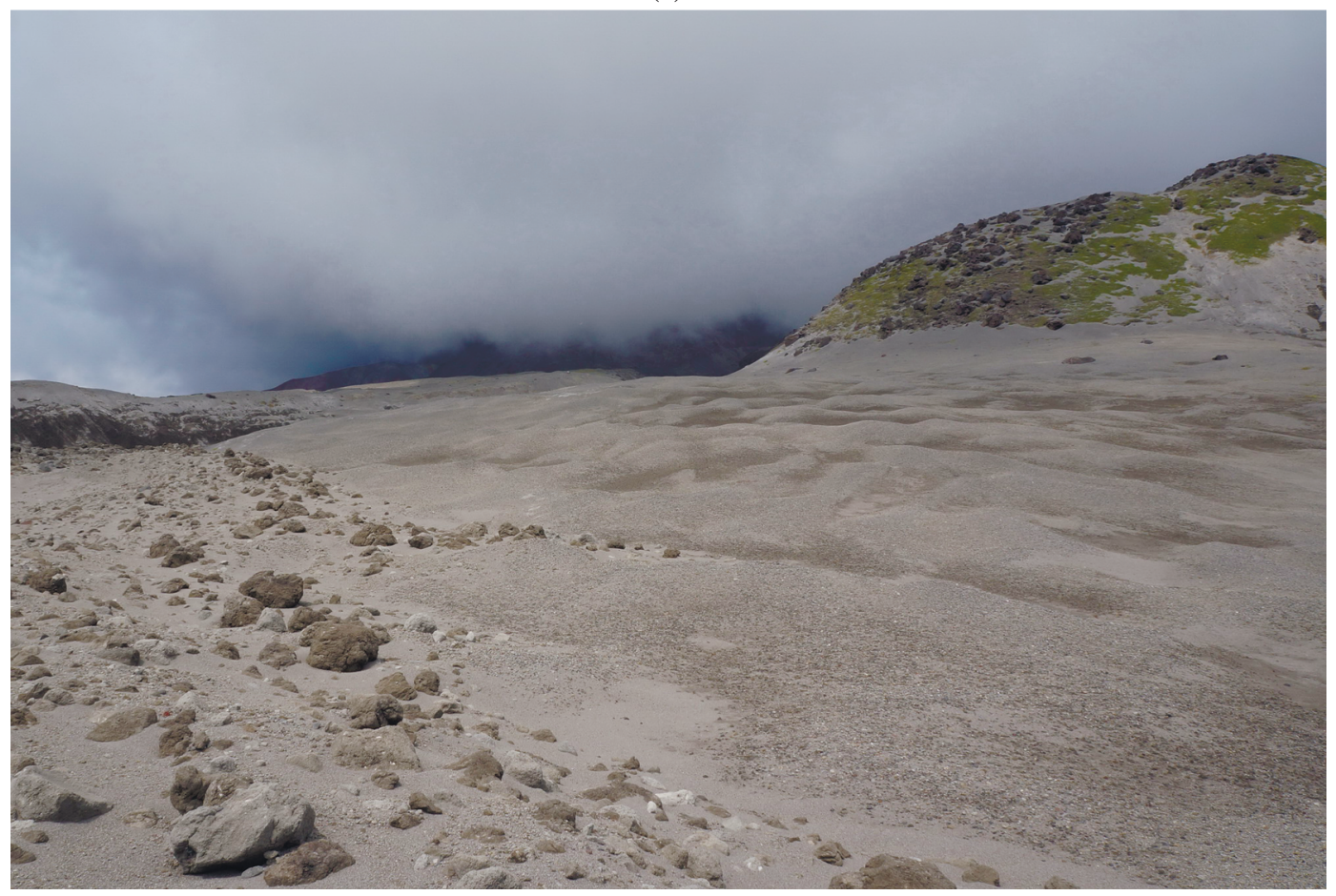

Рис. 8. Окончание 
местами размыты после снеготаяния (см. рис. 8б). Характеристики глыб и заполнителя потока не отличались от таковых отложений в каньоне.

Наибольшая масса пирокластических отложений извержения 15 марта находилась в долине Восточная - они перекрывали ее почти до середины и далее двумя узкими языками спускались вдоль северного и южного бортов до выхода из долины (см. рис. 7). В небольшой доле отложения потоков наблюдались и в долине Южная. Отложения пирокластики в верховьях долины Восточная отличались наличием более крупных глыб пластичной лавы (до 4-5 м) и плотных разновидностей (до 3 м). На значительно большую мощность этих отложений указывает более высокая яркостная температура $\left(-12^{\circ} \mathrm{C}\right)$ по сравнению с отложениями потоков $\left(-23^{\circ} \mathrm{C}\right)$ в других долинах, данные получены по спутниковой информации за 19 марта 2019 г. [Гирина и др., 2020].

На западных склонах вулкана маломощные (до 3 м) пирокластические потоки лежали в узких неглубоких ложбинах, основную их массу составляли фрагменты пластичной лавы среднего размера (до 30-50 см, хотя встречались и крупные блоки лавы размером 1.5 м), погруженные в среднезернистую песчаную массу зеленоватого оттенка (см. рис. 8в).

Отложения пирокластических волн наблюдались на всех склонах вулкана, но распределение их было неравномерным. Так как образования пирокластических волн непосредственно связаны с формированием пирокластических потоков [Гирина, 1998], их объемы зависели от объемов потоков. Наименьшая мощность отложений пирокластических волн отмечалась на западном склоне вулкана - склон был как бы присыпан зеленоватым песком, мощность которого в некоторых местах на снежниках составляла 4-5 см, кроме того, на песке в беспорядке присутствовали такие же как в потоке, но небольшие по размеру (до 10 см) пористые зеленоватого цвета округленные вулканические бомбы и остроугольные обломки вспененной лавы. Наибольшая мощность отложений пирокластических волн (до 2 м) была в северной части верховьев долины Восточная.

Зона распространения образований пирокластических волн хорошо выражена на спутниковом снимке Sentinel-2B (см. рис. 7) и подтверждена полевыми исследованиями - на южном и юговосточном склонах вулкана они ограничивались северным склоном экструзии Разлатый и занимали все поле пирокластических отложений вплоть до северных склонов вулкана и отрогов соседнего вулкана Камень. В ложбине возле Разлатого отложения волн лежали на снежнике и представляли собой хорошо отсортированные пески зеленоватого оттенка мощностью до 10-15 см. На их поверхности в небольшом количестве встречались округленные фрагменты пластичной лавы размером до 30-40 см. Отложения пирокластических волн плащом покрывали юго-восточные и восточные склоны вулкана и имели такие же вид и размерность, как и пески у экструзии Разлатый. Слева от каньона у купола Лохматый и в верховьях долины Восточная отложения пирокластических волн сформировали холмистый дюнный рельеф (см. рис. 8г), типичный для образований пирокластических волн [Гирина, 1998; Girina, 1997]. Плотность ненарушенного сложения отложений пирокластических волн варьировалась в

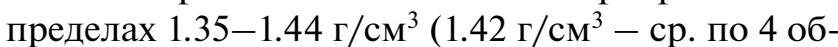
разцам). Заполнитель отложений пирокластических волн был представлен среднезернистым песком зеленоватого оттенка с преобладанием частиц размером 0.25-0.5 мм (см. рис. 6). Судя по хорошо выраженному одномодальному распределению песчаных частиц, эти отложения являются образованиями приземных пирокластических волн [Гирина, 1998].

\section{Химический и минеральный состав продуктов эксплозивного извержения Безымянного 15 марта 2019 z.}

Продукты извержения относятся к известково-щелочным умереннокалиевым андезибазальтам $\left(\mathrm{SiO}_{2}=54.84-56.29\right.$ мас. \%, $\mathrm{K}_{2} \mathrm{O}=0.86-$ 1.05 мaс. $\%, \mathrm{MgO}=3.62-4.78$ мас. $\%, \mathrm{FeO}^{*} / \mathrm{MgO}=$ $=1.61-1.83$, пересчитано на безводный остаток и приведено к сумме оксидов 100\%) (рис. 9). Фрагменты ювенильной лавы в отложениях пирокластических потоков и заполнитель пирокластических потоков и волн близки по составу и содержат 55.01-55.64 мас. \% кремнекислоты (см. табл. 1).

Фрагменты ювенильной лавы сильно пористые (50-70\% от общей площади шлифов), порфировые (от 10-15 до 30-35 об. \% вкрапленников), с тонкораскристаллизованной основной массой (рис. 10a). Среди вкрапленников преобладает плагиоклаз (до 80-90\%), присутствуют ортопироксен, клинопироксен и микровкрапленники титаномагнетита. В подчиненных количествах присутствует апатит и реликты амфибола. Составы минералов и стекол были получены в лаборатории локальных методов исследования вещества кафедры петрологии геологического факультета МГУ при помощи сканирующего электронного микроскопа JSM-6480 LV с приставкой Oxford XMaxN для локального микроанализа.

Плагиоклаз вкрапленников представлен тремя генерациями, выделяющимися по размерности кристаллов. Наиболее крупные плагиоклазы достигают 3-4 мм и составляют $~ 10 \%$ от общего количества фенокристаллов. Плагиоклазы преобладающей генерации - таблитчатые кристаллы длиной до 1 мм (реже до 2 мм) со сложной зональ- 

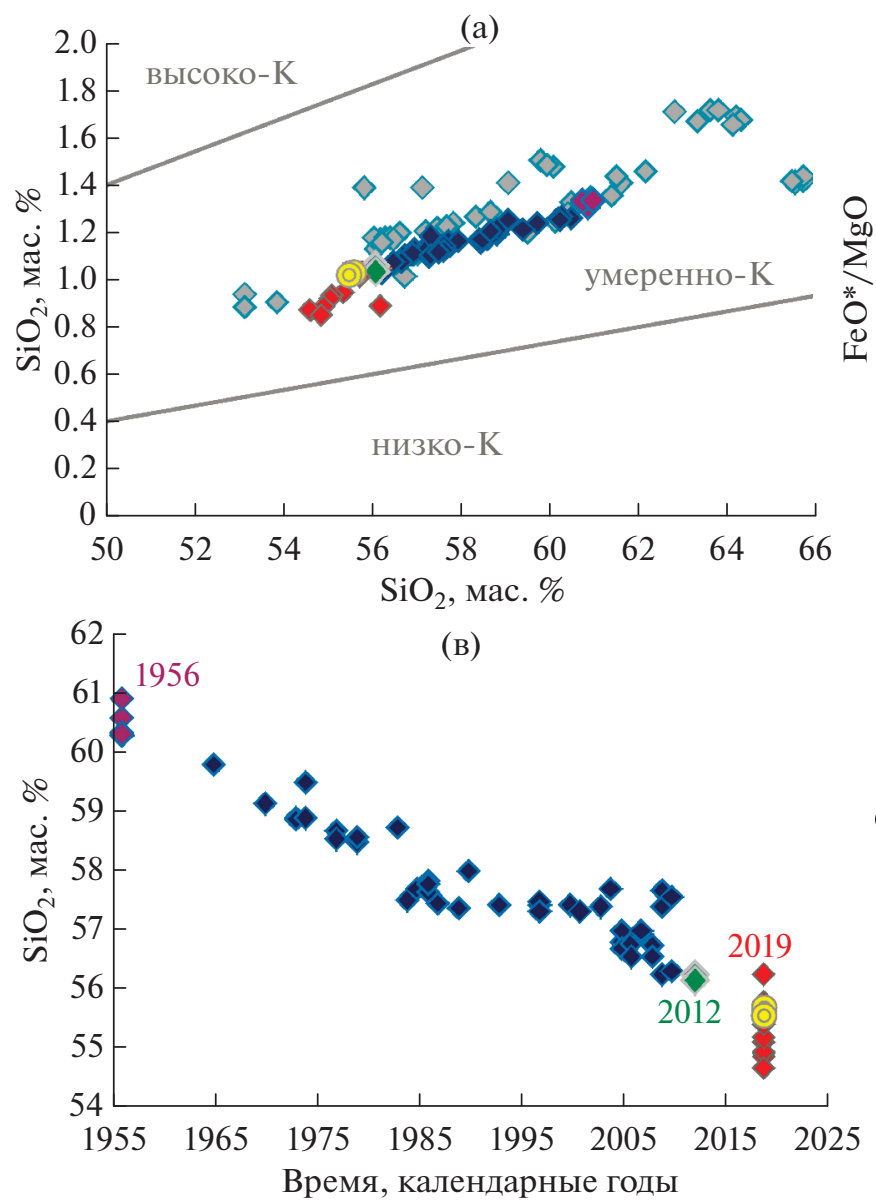

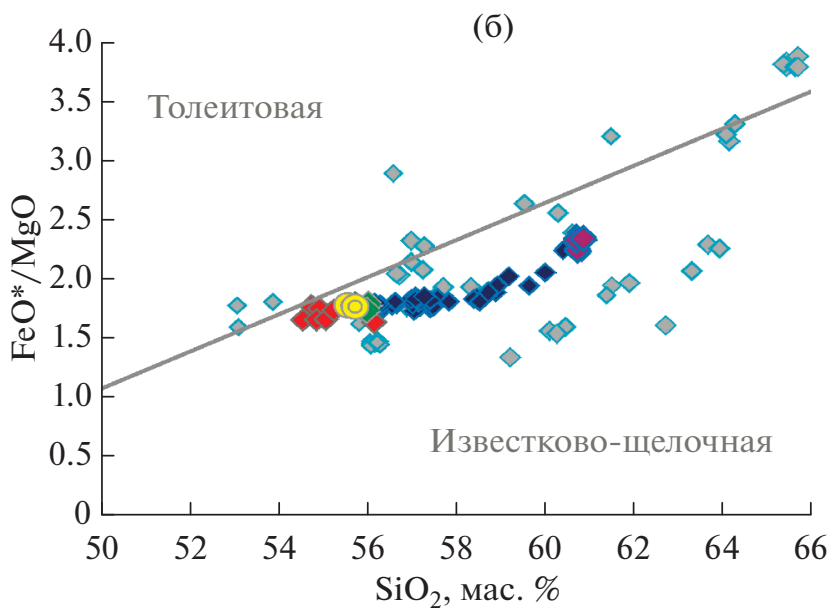

Продукты извержения 15 марта 2019 г.:

з заполнитель пирокластического потока, материал пирокластических волн и тефра

() фрагменты ювенильной лавы из отложений пирокластического потока

Продукты предшествующих извержений:

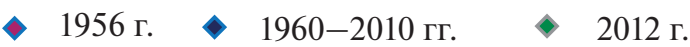
породы постройки в. Безымянный и экструзивных куполов

Рис. 9. Составы пород современного эруптивного цикла вулкана Безымянный, в том числе 15 марта 2019 г., и более ранних этапов активности.

Составы продуктов извержений 1956-2010 гг. приведены по [Гирина, Горбач, 2006; Озеров и др., 1997; Turner et al., 2013]; 2012 г. - по [Давыдова и др., 2017]; более древних - по [Богоявленская и др., 1991; Брайцева и др., 1990; Almeev et al., 2013].

ностью. Для крупных кристаллов характерна ритмичная зональность, в среднем, с двумя-тремя крупными ритмами (более основная зона, часто резорбированная и/или осложненная пятнистой зональностью, сменяется более кислой с осциллярной зональностью и многочисленными тонкими зонами со следами растворения) (см. рис. 10б, в). В ядрах с пятнистой зональностью наиболее обогащенный анортитовым миналом плагиоклаз отвечает $\sim \mathrm{An}_{70}$, в резорбированных зонах в средней части кристаллов - до $\sim \mathrm{An}_{76}$, в зонах с осциллярной зональностью - $\mathrm{An}_{60-65}$. Крупные микролиты (до $100 \mu \mathrm{m})$ также обладают ритмичной зональностью, часто со следами растворения (от $\mathrm{An}_{72}$ в относительно основных зонах до $\mathrm{An}_{59}$ в более кислой кайме). Мелкие микролиты - гомогенные, футляровидные и/или скелетные кристаллы, чей количественный анализ затруднен в силу размера, по яркости изображения в отраженных электронах отвечают краевым частям крупных кристаллов.
Пироксены (ортопироксен и клинопироксен) присутствуют в виде вкрапленников (призматические и длиннопризматические кристаллы длиной обычно не более 0.8 мм) и крупных микролитов (см. рис. 10б). Для всех пироксенов характерны практически гомогенные ядра (Mg\# 65-66 для ортопироксена и 71-72 для клинопироксена), окруженные более магнезиальной каймой (Mg\# 74-76 для ортопироксена и 75-79 для клинопироксена), нередко обладающей собственной ритмичной зональностью. Часто встречаются сростки двух пироксенов и нарастание клинопироксена на ортопироксен.

Рудный минерал представлен титаномагнетитом, изредка со слабыми следами распада твердого раствора. Титаномагнетит образует микровкрапленники и микролиты.

В качестве акцессорного минерала присутствует апатит.

Единичные реликты амфибола, отвечающие чермакит-паргаситовому ряду, окружены мощной 

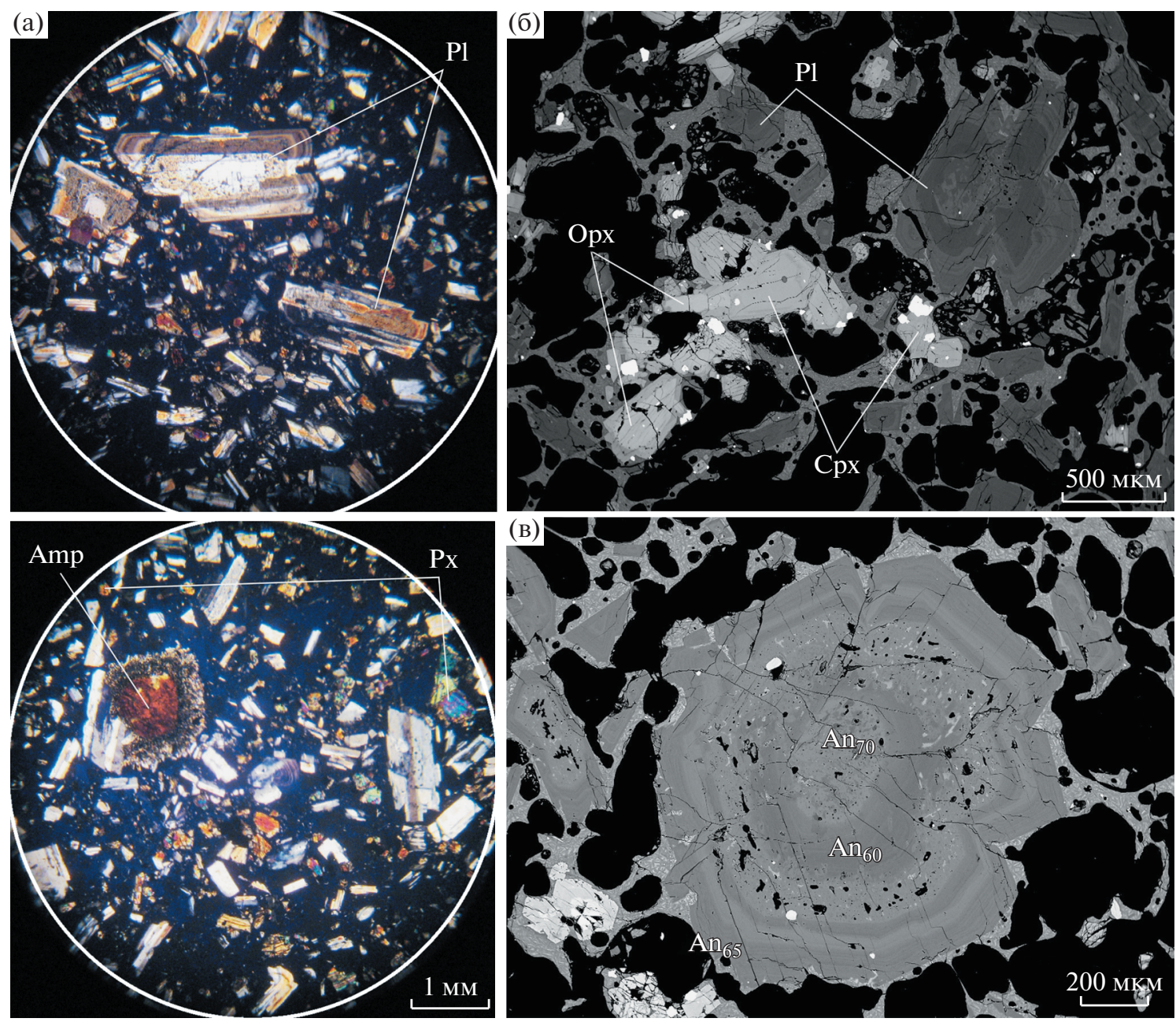

Рис. 10. Общий вид фрагмента лавы андезибазальтового состава из отложений пирокластических потоков: а - в скрешенных николях, б - в отраженных электронах, в - типичный зональный вкрапленник плагиоклаза в отраженных электронах. Обозначения: Pl - плагиоклаз, An - содержание анортитового минала в плагиоклазе, Px - пироксен, Срх - клинопироксен, Орх - ортопироксен, Аmp - амфибол.

двучленной 2Px-Pl-Mag каймой или же полностью замещены двупироксен-плагиоклаз-титаномагнетитовым агрегатом.

Основная масса пород тонкораскристаллизована и состоит из многочисленных скелетных микролитов плагиоклаза, среди которых изредка встречаются микролиты пироксенов и апатита. Интерстициальное стекло отвечает дацитовому/андезидацитовому составу.

\section{ОБСУЖДЕНИЕ МАТЕРИАЛОВ}

\section{Динамика эксплозивного извержения вулкана Безымянный 15 марта 2019 г.}

Как было сказано выше, подготовка эксплозивного извержения вулкана продолжалась 21 день. В течение 17 ч до пароксизмального события количество раскаленных лавин постоянно росло, и в парогазовом шлейфе вулкана отмечался пепел. За
10 ч до извержения температура термальной аномалии вулкана резко повысилась - вероятно, в его кратер стали внедряться свежие высокотемпературные порции ювенильного вещества. Мощная парогазовая колонна, наблюдавшаяся над вулканом в течение 9-10 ч перед эксплозивной фазой извержения, указывала на поступление лавы с высоким содержанием летучих компонентов.

Эксплозивная фаза извержения началась в 17:10 UTC 15 марта взрывами умеренной силы, в результате которых материал раскаленных лавин и пирокластических потоков поступал на восточные склоны вулкана. Начиная с 17:22 UTC, мощнейшие взрывы обрушивали раскаленные лавины и пирокластические потоки на все склоны вулкана. В 17:29-17:45 UTC в результате серии сильных направленных взрывов, эруптивное облако со скоростью 60-80 км/ч перемещалось на северо-восток от вулкана, хотя ветер был запад- 
ным. О направленности взрывов свидетельствует также мощная толща отложений на северо-восточном склоне Безымянного (см. рис. 1), а также грубозернистость и остроугольность материала тефры в северо-восточном направлении на расстояниях 10-12 км от вулкана. Вероятно, в это время разрушалась и выбрасывалась частично дегазированная (вспененная) затвердевшая лава первых порций магматического вещества, заполнявшая кратер вулкана в течение экструзивной фазы.

Пароксизмальная фаза эксплозивного извержения продолжалась около 7.5 ч - непрерывный вынос пепла из вулкана, формирование пирокластических потоков и пеплового шлейфа происходили примерно до 00:10 UTC 16 марта. После разрушения взрывами порций дегазированной лавы из кратера вулкана взрывами стало выбрасываться высокотемпературное вещество, материал которого формировал основную массу лавовых блоков в пирокластических потоках. Вероятно, эти взрывы также имели направленность, т.к. основная масса пирокластических отложений сосредоточена на восточных и юго-восточных склонах вулкана. Заполнитель пирокластических потоков и заполнитель пирокластических волн представлял собой единую субстанцию, появлявшуюся во время взрывов и выбросов высокогазонасыщенного ювенильного материала из кратера вулкана, а также при явлениях автоэксплозивности при движении пластичных блоков лав в пирокластических потоках по склонам Безымянного. Высокая газонасыщенность пирокластических отложений, крутизна открытых склонов вулкана с небольшим снежным покровом привели к тому, что отдельные пластичные блоки лавы разного размера в результате сальтации оказались на всех склонах вулкана на удалении до 8-10 км от кратера, так же, как и отложения пирокластических волн. Отложения пирокластических потоков концентрировались в основном в глубоких долинах на склонах вулкана. Отложения пирокластических волн помимо площадного распространения иногда приобретали вид своеобразных песчаных потоков. Такой поток образовался, к примеру, в ложбине возле северного склона экструзии Разлатый, которая послужила препятствием на пути движения пирокластических волн.

\section{Геологический эффект эксплозивного извержения Безымянного 15 марта 2019 г.}

В результате извержения облик склонов вулкана изменился - например, профиль каньона у северо-восточного подножия экструзии Лохматый из V-образного стал корытообразным, устьевая его часть полностью перекрыта отложениями пирокластического потока; ложбины на северном и восточном склонах вулкана заполнены отложениями пирокластических потоков и пирокластических волн; в верховьях долины Восточная образовались крупные отложения свежей пирокластики.

Согласно спутниковым данным, протяженность отложений пирокластических потоков в долине Восточная была около 8 км, на юго-восточном склоне в каньоне у экструзии Лохматый - 7 км, на западном склоне - 3.5-4 км. Площадь образований пирокластических потоков и пирокластических

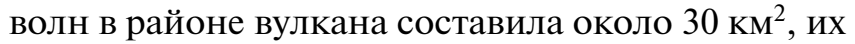
объем оценивается в $0.1-0.2 \mathrm{KM}^{3}$.

Общая площадь пеплопадов, связанных с распространением эруптивного облака вулкана, согласно спутниковым данным, к 03:00 UTC 16 марта составляла около 211 тыс. км², объем отложений тефры, исходя из ее мощности в районе вулкана и на о. Беринга, можно приблизительно оценить как $0.01-0.02$ км$^{3}$.

Основываясь на расчетах выноса тефры в зависимости от высоты эруптивного столба, описанных в работах [Carazzo et al., 2008; Dacre et al., 2011; Kaminski et al., 2011; Mastin et al., 2009; Wilson, Walker, 1987], при высоте эруптивной колонны 12 км над кратером расход тефры вулкана Безымянный 15 марта 2019 г. составил от 2700 до 6700 тыс. кг/с. Зная, что продолжительность наиболее мощной фазы извержения была 960 с (с 17:29 до 17:45 UTC 15 марта), за это время было извергнуто от 2.6 до 6.4 млн т тефры. Используя для

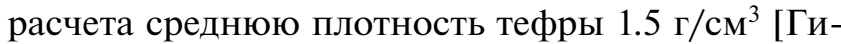
рина, 1998], получим объем тефры от 0.0017 до $0.004 \mathrm{Kм}^{3}$. Учитывая то, что непрерывный вынос пепла продолжался до 00:10 UTC 16 марта, VEI извержения оценивается как 3 .

Извержение 15 марта 2019 г. в ряду других эксплозивных извержений вулкана Безымянный

По площади распространения и объему отложений пирокластических потоков и волн это эксплозивное извержение является одним из сильнейших в современной истории вулкана Безымянный. Например, в период 1965-2010 гг. наиболее сильное извержение вулкана произошло в 1985 г. (площадь отложений пирокластических потоков $12.25 \mathrm{kM}^{2}$, объем изверженных продуктов $0.05 \mathrm{KM}^{3}$ ), за этот период вулканом было извергнуто примерно $0.41 \mathrm{Kм}^{3}$ продуктов [Girina, 2013]. Во время извержения 15 марта 2019 г. отложения пирокластических потоков и волн заняли площадь около $30 \mathrm{KM}^{2}$, объем извергнутых продуктов оценивается в $0.1-0.2 \mathrm{KM}^{3}$.

Похожие на рассматриваемое извержение события и продукты на вулкане Безымянный наблюдались лишь однажды - в январе 2005 г. [Гирина, Горбач, 2006]. Тогда, как и сейчас, пирокластические потоки в долинах Восточная и Южная были сложены преимущественно блока- 
ми пластичных лав. Отложения пирокластических волн в долине Восточная сформировали дюнный рельеф, на южных и юго-восточных склонах вулкана они лежали в долинах ручьев и на открытых поверхностях в виде песчаных потоков мощностью до 0.5 м. Объем образований пирокластических потоков и волн был крупным - около $0.05 \mathrm{kм}^{3}$. Отложения тефры были грубозернистыми, например, в 65 км от вулкана в них преобладали частицы размером 0.5-2.0 мм. Кроме этого, было отмечено, что лавовый поток, сформированный после январского извержения 2005 г. на западном склоне лавового купола Безымянного, являлся менее вязким по сравнению с лавовыми потоками предыдущих извержений [Гирина, Горбач, 2006].

\section{Особенности химического состава продуктов извержения}

Андезибазальты эксплозивного извержения 15 марта 2019 г. являются наиболее основными разностями среди пород современного эруптивного цикла вулкана Безымянный (см. рис. 9). По сравнению с ювенильными продуктами катастрофического извержения 30 марта 1956 г. содержание $\mathrm{SiO}_{2}$ в лавах последнего извержения снизилось на $\sim 6$ мас. \%. На фоне общего антидромного тренда изменения состава пород вулкана с 1956 по 2019 гг. выделяются несколько периодов, отличающихся интенсивностью снижения кремнекислоты (см. рис. 9). Так, с 1956 г. по начало 1980-х гг. содержание $\mathrm{SiO}_{2}$ снизилось с 61 до 57.5-58 мас. \%. В этот же период произошла смена роговообманковой минеральной ассоциации 1956-1969 гг. на роговообманково-пироксеновую, а затем, в 1979-1981 гг. - на двупироксеновую ассоциацию [Кадик и др., 1986], которая в течение 20 лет (до начала 2000 г.) оставалась практически неизменной [Turner et al., 2013].

Выраженная тенденция к прогрессивному снижению $\mathrm{SiO}_{2}$ ниже 57 мас. \% в породах последовательных извержений проявляется с 2005 г. (см. рис. 9). Снижение $\mathrm{SiO}_{2}$ и рост $\mathrm{MgO}$ отмечены не только в валовом составе пород, но и в составах интерстициальных стекол и расплавных включений в минералах андезибазальтов [Shcherbakov et al., 2011].

Геологические и тефрохронологические исследования [Богоявленская и др., 1991; Брайцева и др., 1990] показали, что в истории эруптивной активности вулкана Безымянный смена роговообманковых и роговообманково-пироксеновых андезитов на двупироксеновые андезиты и андезибазальты происходила неоднократно. После пароксизмальных событий, подобных катастрофическому извержению 1956 г. следовали сравнительно длительные (100-400 лет) эруптивные циклы, в течение которых извергались, в основном, двупирок- сеновые андезиты и андезибазальты. Текущее состояние вулкана, по всей видимости, отвечает середине такого цикла.

\section{ЗАКЛЮЧЕНИЕ}

1. Эксплозивное извержение Безымянного 15 марта 2019 г. было самым сильным в ряду пароксизмальных извержений 1965-2019 гг., связанных с ростом лавового купола вулкана.

2. Эксплозивное извержение вулкана Безымянный 15 марта 2019 г. было предсказано учеными KVERT за 6.5 ч до его начала.

3. Эксплозии подняли пепел до 15 км над уровнем моря (до 12 км над вулканом). Эксплозивная фаза извержения продолжалась 7.5 ч.

4. Общая площадь пеплопадов, связанных с распространением эруптивного облака вулкана, к 03:00 UTC 16 марта составляла около 210.4 тыс. км², в том числе на суше - 15 тыс. км². Объем тефры варьируется от 0.0017 до $0.004 \mathrm{KM}^{3}$.

5. Площадь отложений пирокластических потоков и пирокластических волн в районе вулкана составила около $30 \mathrm{KM}^{2}$, их объем оценивается в $0.1-0.2 \mathrm{KM}^{3}$.

6. Продукты эксплозивного извержения вулкана относятся к известково-щелочным умереннокалиевым андезибазальтам. Они являются наиболее основными разностями среди пород современного эруптивного цикла вулкана Безымянный.

7. Общий объем продуктов эксплозивного извержения Безымянного 15 марта 2019 г. оценивается в $0.1-0.2 \mathrm{KM}^{3}$, VEI -3 .

\section{ИСТОЧНИК ФИНАНСИРОВАНИЯ}

Работа выполнена при поддержке Российского научного фонда (проект № 16-17-00042).

\section{СПИСОК ЛИТЕРАТУРЫ}

Башарина Л.А. Вулканические газы Камчатки / Автореф. дисс. ... канд. геол.-мин. наук. ПетропавловскКамчатский: СО ИВ АН СССР, 1966. 30 с.

Богоявленская Г.Е., Брайцева О.А., Мелекесцев И.В.и др. Вулкан Безымянный // Действующие вулканы Камчатки. В 2-х томах. М.: Наука, 1991. Т. 1. С. 168-194.

Брайцева О.А., Мелекесцев И.В., Богоявленская Г.Е., Максимов А.П. Вулкан Безымянный: история формирования и динамика активности // Вулканология и сейсмология. 1990. № 2. С. 3-22.

Гирина О.А. Пирокластические отложения современных извержений андезитовых вулканов Камчатки и их инженерно-геологические особенности / Отв. ред. И.В. Мелекесцев. Владивосток: Дальнаука, 1998. 174 с. Гирина О.А. Спутниковые данные высокого разрешения для уточнения положения разломных зон в пределах Ключевской группы вулканов Камчатки // Совре- 
менные проблемы дистанционного зондирования Земли из космоса. 2016. Т. 13. № 6. С. 148-156. https://doi.org/10.21046/2070-7401-2016-13-6-148-156

Гирина О.А., Горбач Н.В. Извержение вулкана Безымянный 11 января 2005 г. // Проблемы эксплозивного вулканизма (к 50-летию катастрофического извержения вулкана Безымянный) // Материалы Международного симпозиума, Петропавловск-Камчатский, 25-30 марта 2006 г. Петропавловск-Камчатский: ИВиС ДВО РАН, 2006. С. 85-94.

Гирина О.А., Крамарева Л.С., Лупян Е.А. и др. Применение данных спутника Himawari для мониторинга вулканов Камчатки // Современные проблемы дистанционного зондирования Земли из космоса. 2017а. Т. 14. № 7. C. $65-76$.

https://doi.org/10.21046/2070-7401-2017-14-7-65-76

Гирина О.А., Лупян Е.А., Мельников Д.В. и др. Извержения Северной группы вулканов Камчатки 14-18 июня 2017 года // Современные проблемы дистанционного зондирования Земли из космоса. 2017б. Т. 14. № 3. C. $317-323$.

https://doi.org/10.21046/2070-7401-2017-14-3-317-323

Гирина О.А., Мельников Д.В., Демянчук Ю.В., Маневич А.Г. Извержение вулкана Безымянный в 2016-2017 гг. по данным KVERT // Вулканизм и связанные с ним процессы // Материалы XX региональной научной конференции, посвященной Дню вулканолога, 30-31 марта 2017 г. Петропавловск-Камчатский: ИВиС ДВО РАН, 2017в. C. 14-17.

Гирина О.А., Мельников Д.В., Маневич А.Г. Спутниковый мониторинг вулканов Камчатки и Северных Курил // Современные проблемы дистанционного зондирования Земли из космоса. 2017г. Т. 14. № 6. С. 194-209.

https://doi.org/10.21046/2070-7401-2017-14-6-194-209

Гирина О.А., Лупян Е.А., Мельников Д.В. и др. Извержение вулкана Безымянный 20 декабря 2017 года // Современные проблемы дистанционного зондирования Земли из космоса. 2018a. Т. 15. № 3. С. 88-99. https://doi.org/10.21046/2070-7401-2018-15-3-88-99

Гирина О.А., Лупян Е.А., Сорокин А.А. и др. Комплексный мониторинг эксплозивных извержений вулканов Камчатки / Отв. ред. О.А. Гирина. ПетропавловскКамчатский: ИВиС ДВО РАН, 2018б. 192 с.

Гирина О.А., Мельников Д.В., Маневич А.Г. и др. Вулкан Безымянный в 2016-2018 гг. по данным KVERT // Вулканизм и связанные с ним процессы // Материалы XXI региональной научной конференции, посвященной Дню вулканолога, 29-30 марта 2018 г. ПетропавловскКамчатский: ИВиС ДВО РАН, 2018в. С. 28-31.

Гирина О.А., Лупян Е.А., Мельников Д.В. и др. Создание и развитие информационной системы “Дистанционный мониторинг активности вулканов Камчатки и Курил” // Современные проблемы дистанционного зондирования Земли из космоса. 2019а. Т. 16. № 3. С. 249-265. https://doi.org/10.21046/2070-7401-2019-16-3-249-265

Гирина О.А., Мельников Д.В., Маневич А.Г. и др. Извержение вулкана Безымянный 20 января 2019 г. // Вулканизм и связанные с ним процессы // Материалы XXII Всероссийской научной конференции, посвященной Дню вулканолога, 28-29 марта 2019 г. ПетропавловскКамчатский: ИВиС ДВО РАН, 2019б. С. 59-62.

Гирина О.А., Мельников Д.В., Маневич А.Г. и др. Характеристика событий эксплозивного извержения вулкана
Безымянный 15 марта 2019 г. по спутниковым данным // Современные проблемы дистанционного зондирования Земли из космоса. 2020. Т. 17. № 3. С. 102-114. https://doi.org/10.21046/2070-7401-2020-17-3-102-114

Давыдова В.О., Щербаков В.Д., Плечов П.Ю., Перепелов А.Б. Петрологическая характеристика мафических включений в продуктах современных извержений вулкана Безымянный, Камчатка, 2006-2012 гг. // Петрология. 2017. Т. 25. № 6. С. 609-634.

Дубик Ю.М., Меняйлов И.А. Новый этап эруптивной деятельности вулкана Безымянный // Вулканы и извержения. М.: Наука, 1969. С. 38-77.

Кадик А.А., Максимов А.П., Иванов Б.В. Физико-химические условия кристаллизации и генезис андезитов (на примере Ключевской группы вулканов)/ Отв. ред. Л.В. Дмитриев. М.: Наука, 1986. 157 с.

Лупян Е.А., Милехин О.Е., Антонов В.Н. и др. Система работы с объединенными информационными ресурсами, получаемыми на основе спутниковых данных в центрах НИЦ “Планета” // Метеорология и гидрология. 2014. № 12. С. 89-97.

Лупян Е.А., Прошин А.А., Бурцев М.А. и др. Центр коллективного пользования системами архивации, обработки и анализа спутниковых данных ИКИ РАН для решения задач изучения и мониторинга окружающей среды // Современные проблемы дистанционного зондирования Земли из космоса. 2015. Т.12. № 5. C. 263-284.

Озеров А.Ю., Арискин А.А., Кайл Ф. и др. Петролого-геохимическая модель генетического родства базальтового и андезитового магматизма вулканов Ключевской и Безымянный, Камчатка // Петрология. 1997. Т. 5. № 6. C. 614-635.

Carazzo G., Kaminski E., Tait $S$. On the rise of turbulent plumes: Quantitative effects of variable entrainment for submarine hydrothermal vents, terrestrial and extra terrestrial explosive volcanism // J. of Geoph. Res. 2008. V. 113. B09201. P. 1-19.

https://doi.org/10.1029/2007JB005458

Dacre H., Grant A., Hogan R. et al. Evaluating the structure and magnitude of the ash plume during the initial phase of the 2010 Eyjafjallajökull eruption using lidar observations and NAME simulations // J. of Geoph. Res. 2011. V. 116. D00U03. P. $1-15$.

https://doi.org/10.1029/2011JD015608

Girina O.A. Chronology of Bezymianny Volcano activity, 1956-2010 // J. of Volcanol. and Geoth. Res. 2013. V. 263. P. 22-41.

https://doi.org/10.1016/j.jvolgeores.2013.05.002

Girina O.A. Pyroclastic surge deposits of Bezymianny volcano // Volcanol. and Seismol. 1997. V. 18. № 5. P. 547560.

Gordeev E.I., Girina O.A. Volcanoes and their hazard to aviation // Herald of the Russian Academy of Sciences. 2014. V. 84. № 1. P. 1-8.

https://doi.org/10.1134/S1019331614010079

Gordeev E.I., Girina O.A., Loupian E.A. et al. The VolSatView information system for Monitoring the Volcanic Activity in Kamchatka and on the Kuril Islands // J. of Volcanol. and Seismol. 2016. V. 10. № 6. P. 382-394.

https://doi.org/10.1134/S074204631606004X 
Kaminski E., Tait S., Ferrucci F. et al. Estimation of ash injection in the atmosphere by basaltic volcanic plumes: The case of the Eyjafjallajökull 2010 eruption // J. of Geoph. Res. 2011. V. 116. B00C02. P. 1-10. https://doi.org/10.1029/2011JB008297

Mastin L.G., Guffanti M., Servranckx R. et al. A multidisciplinary effort to assign realistic source parameters to models of volcanic ash-cloud transport and dispersion during eruptions // J. of Volcanol. and Geoth. Res. 2009. V. 186. P. 10-21.

https://doi.org/10.1016/j.jvolgeores.2009.01.008

Ozerov A.Yu., Girina O.A., Zharinov N.A. et al. Eruptions in the Northern Group of Volcanoes, in Kamchatka, during the Early 21st Century // J. of Volcanol. and Seismol. 2020. V. 14. № 1. P. 1-17.

https://doi.org/10.1134/S0742046320010054
Turner S.J., Izbekov P., Langmuir C. The magma plumbing system of Bezymianny Volcano: Insights from a 54 year time series of trace element whole-rock geochemistry and amphibole compositions // J. of Volcanol. and Geoth. Res. 2013. V. 263. P. 108-121.

Shcherbakov V.D., Plechov P.Yu., Izbekov P. et al. Plagioclase zoning as an indicator of magma processes at Bezymianny Volcano, Kamchatka // Contributions to Mineralogy and Petrology. 2011. V. 162. № 1. P. 83-99.

Wilson L., Walker G.P.L. Explosive volcanic eruptions VI: ejecta dispersal in plinian eruptions: the control of eruption conditions and atmospheric properties // Geoph. J. of the Royal Astronom. Soc. 1987. V. 89. P. 657-679.

\title{
The 15 March 2019 Bezymianny Volcano Explosive Eruption and its Products
}

\author{
O. A. Girina ${ }^{1, ~ *, ~ N . ~ V . ~ G o r b a c h " 1, ~ V . ~ O . ~ D a v y d o v a ' ~}{ }^{2}$ D. V. Melnikov', \\ T. M. Manevich ${ }^{1}$, A. G. Manevich ${ }^{1}$, and Yu. V. Demyanchuk ${ }^{1}$ \\ ${ }^{1}$ Institute of Volcanology and Seismology, Far East Branch, Russian Academy of Sciences, \\ bul'var Piipa, 9, Petropavlovsk-Kamchatsky, 683006 Russia \\ ${ }^{2}$ Faculty of Geology, Lomonosov State University, Leninskie Gory, 1, Moscow, 119991 Russia \\ *e-mail: girina@kscnet.ru
}

\begin{abstract}
Bezymianny volcano is one of the most active volcanoes in Kamchatka and the world. This work describes the preparation, course, products, dynamics and the geological effect of the explosive eruption of the volcano on March 15, 2019. This eruption was predicted 6.5 hours before it began. An analysis of the sequence of eruptive events was carried out using video and satellite monitoring of the volcano, quantitative characteristics of the distribution of pyroclastic deposits were obtained in the information system "Remote monitoring of the activity of the volcanoes of Kamchatka and the Kuril Islands". Explosions raised ash up to $15 \mathrm{~km}$ above sea level (12 km above the volcano), and the eruptive cloud moved to the north-east and east of the volcano. The main area of the territory where ash falls were noting was $210400 \mathrm{~km}^{2}$, including $15000 \mathrm{~km}^{2}$ on land. In addition to tephra, as a result of an explosive eruption, deposits of pyroclastic flows and pyroclastic surges were formed over an area of $30 \mathrm{~km}^{2}$. The total volume of products of the volcano explosive eruption is estimated at $0.1-0.2 \mathrm{~km}^{3}$. The eruption products belong to calc-alkaline moderate potassium basaltic andesites $\left(\mathrm{SiO}_{2}=54.84-56.29 \mathrm{wt} \%\right)$, and have the most mafic composition among the rocks of the modern eruptive cycle of Bezymianny volcano.
\end{abstract}

Keywords: volcano, Bezymianny, explosive eruption, KVERT, forecast, video data, satellite monitoring, VolSatView, Kamchatka 